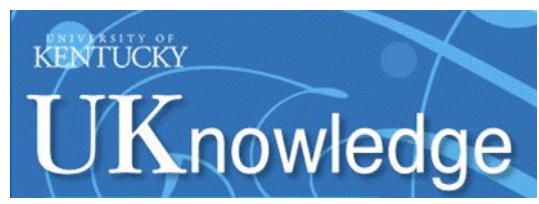

University of Kentucky

UKnowledge

\title{
Importance Considered Organic Versus Inorganic Source of Carbon to Lakes for Calculating Net Effect on Landscape C Budgets
}

Weiqi Lu

Chinese Academy of Sciences, China

Shilu Wang

Chinese Academy of Sciences, China

Kevin M. Yeager

University of Kentucky, kevin.yeager@uky.edu

Fang Liu

Chinese Academy of Sciences, China

Qiangsheng Huang

Chinese Academy of Sciences, China

Follow this and additional works at: https://uknowledge.uky.edu/ees_facpub

Part of the Biogeochemistry Commons, Environmental Sciences Commons, and the Fresh Water See next page for additional authors

Studies Commons

Right click to open a feedback form in a new tab to let us know how this document benefits you.

\section{Repository Citation}

Lu, Weiqi; Wang, Shilu; Yeager, Kevin M.; Liu, Fang; Huang, Qiangsheng; Yang, Yuxue; Xiang, Peng; Lü, Yingchun; and Liu, Chong-qiang, "Importance Considered Organic Versus Inorganic Source of Carbon to Lakes for Calculating Net Effect on Landscape C Budgets" (2018). Earth and Environmental Sciences Faculty Publications. 12. https://uknowledge.uky.edu/ees_facpub/12

This Article is brought to you for free and open access by the Earth and Environmental Sciences at UKnowledge. It has been accepted for inclusion in Earth and Environmental Sciences Faculty Publications by an authorized administrator of UKnowledge. For more information, please contact UKnowledge@lsv.uky.edu. 


\section{Importance Considered Organic Versus Inorganic Source of Carbon to Lakes for Calculating Net Effect on Landscape C Budgets}

Digital Object Identifier (DOI)

https://doi.org/10.1002/2017JG004159

Notes/Citation Information

Published in Journal of Geophysical Research: Biogeosciences, v. 123, issue 4, p. 1302-1317.

@2018. American Geophysical Union. All Rights Reserved.

The copyright holders have granted the permission for posting the article here.

Authors

Weiqi Lu, Shilu Wang, Kevin M. Yeager, Fang Liu, Qiangsheng Huang, Yuxue Yang, Peng Xiang, Yingchun Lü, and Chong-qiang Liu 


\section{Journal of Geophysical Research: Biogeosciences}

\author{
RESEARCH ARTICLE \\ 10.1002/2017JG004159 \\ Key Points: \\ - We integrated lake carbon fluxes in \\ the context of inorganic and organic \\ carbon cycling in a karst catchment \\ from a system prospective \\ - Significance of lake $C$ fluxes to \\ adjustment of land $C$ budgets \\ depends on carbon origins and may \\ be overrated (ignoring inorganic \\ origin) \\ - Partitioning $C$ fluxes between organic \\ and inorganic origins is essential to \\ accurately assess the roles of lakes in \\ global carbon cycle
}

Supporting Information:

- Supporting Information S1

Correspondence to:

S. Wang,

wangshilu@vip.skleg.cn

Citation:

Lu, W., Wang, S., Yeager, K. M., Liu, F. Huang, Q., Yang, Y., et al. (2018). Importance of considered organic versus inorganic source of carbon to lakes for calculating net effect on landscape $C$ budgets. Journal of Geophysical Research: Biogeosciences, 123, 1302-1317. https://doi.org/10.1002/ 2017JG004159

Received 13 SEP 2017

Accepted 27 MAR 2018

Accepted article online 6 APR 2018

Published online 21 APR 2018

2018. American Geophysical Union. All Rights Reserved.

\section{Importance of Considered Organic Versus Inorganic Source of Carbon to Lakes for Calculating Net Effect on Landscape C Budgets}

\author{
Weiqi Lu ${ }^{1,2}\left(D\right.$, Shilu Wang' ${ }^{1}$, Kevin M. Yeager ${ }^{3}$, Fang Liu ${ }^{1,4}$, Qiangsheng Huang ${ }^{1}$, Yuxue Yang ${ }^{1}$, \\ Peng Xiang ${ }^{1}$, Yingchun Lï ${ }^{1,5}$, and Cong-qiang Liu' \\ 'State Key Laboratory of Environmental Geochemistry, Institute of Geochemistry, Chinese Academy of Sciences, Guiyang, \\ China, ${ }^{2}$ University of Chinese Academy of Sciences, Beijing, China, ${ }^{3}$ Department of Earth and Environmental Sciences, \\ University of Kentucky, Lexington, KY, USA, ${ }^{4}$ Now at Baise University, Baise, China, ${ }^{5}$ Now at Yantai Institute of Coastal Zone \\ Research, Chinese Academy of Sciences, Yaitai, China
}

Abstract Lakes and reservoirs transform, emit, and bury carbon that is exported from land and are thus significant components of terrestrial carbon budgets. Their significance is often assessed by integrating these water bodies into terrestrial primary production. However, the transfer of inorganic carbon (IC) is likely a sticking point for these integrations because IC is not part of net ecosystem production. Here we integrated carbon evasion and organic carbon $(\mathrm{OC})$ burial in a lake in the context of inorganic and $O C$ cycling in a karst catchment from a system perspective. The lake emitted carbon dioxide $\left(\mathrm{CO}_{2}\right)$ and buried $\mathrm{OC}$ at rates of $1.0 \pm 0.2$ and $0.9 \pm 0.2 \mathrm{~g} \mathrm{C} \mathrm{m}^{-2} \mathrm{a}^{-1}$, respectively, approximately equaling $13 \%$ and $11 \%$ of catchment net ecosystem production, respectively. These proportions represent significant influences on terrestrial carbon budgets, given an organic origin. However, catchment carbon export is dominated by IC that is derived from carbonates dissolved by soil $\mathrm{CO}_{2}$. Lake $\mathrm{CO}_{2}$ evasion accounts for less than $0.1 \%$ of soil $\mathrm{CO}_{2}$ efflux, suggesting little potential in significantly altering terrestrial carbon budgets. This comparison indicates the significance of aquatic $\mathrm{CO}_{2}$ evasion, requiring an adjustment of terrestrial carbon budgets to recognize their dependence on carbon origins. The significance may be overstated if inorganic origin is ignored. Our study suggests that a careful reassessment of the significance of $\mathrm{CO}_{2}$ evasion and $\mathrm{OC}$ burial in freshwater ecosystems to local and global carbon budgets, with full consideration of their sources, is necessary and pressing.

\section{Introduction}

Lakes and reservoirs, together with other freshwater systems including streams, rivers, wetlands, and ponds, are thought to play important roles in the global carbon cycle by transforming, emitting, and burying amounts of carbon of similar magnitude to total global terrestrial net ecosystem production (NEP; Barros et al., 2011; Butman \& Raymond, 2011; Dean \& Gorham, 1998; Einarsdottir et al., 2017; Hotchkiss et al., 2015; Lundin et al., 2015; Regnier et al., 2013; Tranvik et al., 2009; Wallin et al., 2013). However, inland freshwaters were often regarded as passive conduits, and thus, their roles in delivering carbon from land to ocean were rarely explicitly included in traditional global terrestrial-ocean-atmosphere carbon cycle models (Cole et al., 2007; see also Aufdenkampe et al., 2011). Recent studies have demonstrated that inland waters are actually extremely active components, which participate in and facilitate local and global carbon cycling (e.g., Cole et al., 2007; Hanson et al., 2015; Tranvik et al., 2009). Not accounting for carbon emitted and sequestered by aquatic systems could bias efforts to accurately calculate terrestrial NEP and net ecosystem exchange (Cole et al., 2007; Hotchkiss et al., 2015; Kling et al., 1991; Nakayama, 2017; Tranvik et al., 2009;). A "boundless" concept has been proposed to designate all lateral and vertical carbon fluxes to and from freshwater systems (Battin et al., 2009; Regnier et al., 2013). The new model of carbon cycling, including freshwater fluxes, is expected to serve as a primary tool in managing Earth surface carbon cycling to address increasing carbon sequestration and decreasing carbon emission targets (Battin et al., 2009; Regnier et al., 2013). Great progress has been made in improving global estimates of freshwater $\mathrm{CO}_{2}$ evasion by revisiting three key parameters: the amount of $\mathrm{CO}_{2}$ in freshwaters, the global surface area of inland waters, and the gas transfer velocity, using some new approaches (e.g., Marx et al., 2017; Raymond et al., 2013).

A remaining obstacle to these efforts is that the partitioning and quantification of sources of freshwater $\mathrm{CO}_{2}$ remain poorly constrained (e.g., Cole et al., 2007; Hotchkiss et al., 2015; Kayranli et al., 2010; Marx et al., 2017; 
Journal of Geophysical Research: Biogeosciences

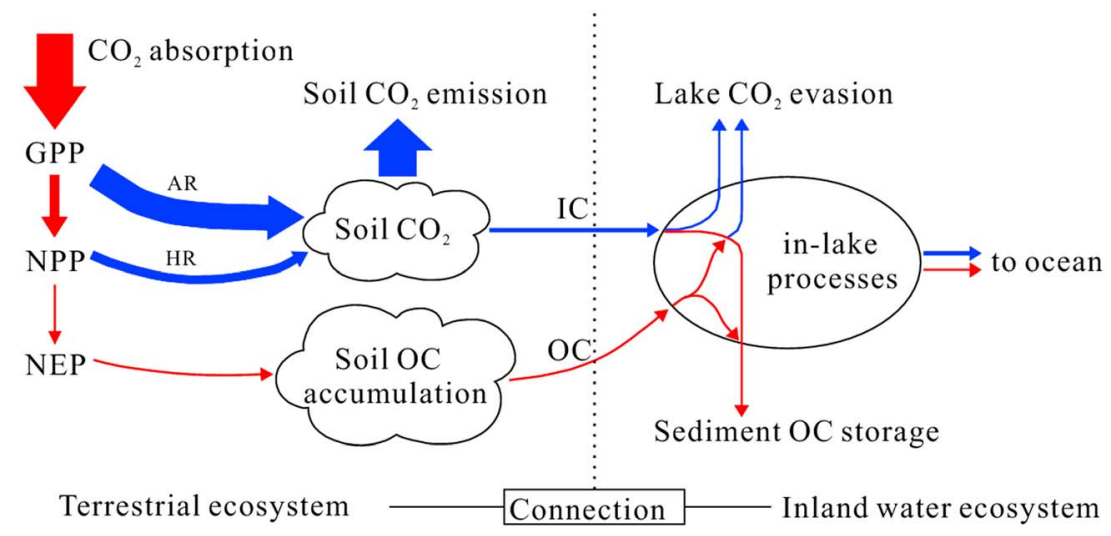

Figure 1. A sketch showing inorganic carbon (blue) and organic carbon (red) pathways of carbon transfer from terrestrial to aquatic ecosystems, which correspond to inorganic and organic origins of lake $\mathrm{CO}_{2}$ (see text), respectively.

Raymond et al., 2013; Regnier et al., 2013; Xu et al., 2014). As shown in Figure 1, $\mathrm{CO}_{2}$ in lakes either originates from the input of soil $\mathrm{CO}_{2}$ (derived from root-related autotrophic respiration $[A R]$ and soil heterotrophic respiration [HR]) through flowing groundwater and rivers (hereinafter referred to as "inorganic origin") or is internally produced by in-lake mineralization of soil organic carbon (OC) from catchments (hereinafter referred to as "organic origin"; Cole et al., 1994) and is likely from both (Buffam et al., 2011). Transport of carbon from land to water is an important factor in controlling the carbon budget in lakes and reservoirs (Cole et al., 1994). Recently, much progress has been made concerning terrestrial carbon export and its coupling with aquatic ecosystems. Ludwig et al. (2011) gave a global average of continental carbon erosion of $0.60 \mathrm{GtC} \mathrm{yr}^{-1}$, of which $0.37 \mathrm{GtC} \mathrm{yr}^{-1}$ can be attributed to OC, and the remaining $0.23 \mathrm{GtC}_{\mathrm{yr}}^{-1}$ to inorganic carbon ( $\mathrm{IC}_{;} \mathrm{CO}_{2}$ as a form of $\mathrm{HCO}_{3}{ }^{-}$). Tian et al.'s (2015) modeling results suggested that climate variability is the primary factor in causing interannual variability of OC and IC export. Nakayama (2017) developed an advanced model which coupled hydrology-carbon cycling in terrestrial-aquatic linkages and the interplay between inorganic and $O C$, and produced horizontal and vertical carbon fluxes for rivers, which are in good agreement with prior research. However, the connections of carbon between terrestrial and aquatic systems in terms of type (IC and OC), strength, spatial extent, and influence (Figure 1) remain poorly constrained (Buffam et al., 2011).

A close relationship between dissolved $\mathrm{OC}(\mathrm{DOC})$ concentrations and partial pressures of $\mathrm{CO}_{2}\left(\mathrm{pCO}_{2}\right)$ is often observed in lakes and is considered a key piece of evidence to support the view that carbon evasion in freshwater systems is maintained by the input of labile organic matter (organic origin; see Figure 1; e.g., Ask et al., 2012; Cole \& Caraco, 2001; Sobek et al., 2003). The carbon emitted from and stored within lakes is assumed to originate mainly from allochthonous $\mathrm{OC}$ delivered from catchments and thus should be included in estimates of terrestrial net primary production (NPP; e.g., Battin et al., 2009; Cole et al., 2007; Tranvik et al., 2009). The scenario that $O C$ sources predominate in lake carbon input occurs, in particular, in boreal and arctic areas, where tundra ecosystems accumulate $\mathrm{OC}$, which can be subsequently supplied to lakes and rivers by erosion (Einarsdottir et al., 2017; Kling et al., 1991; Strock et al., 2017).

Recently, increasing evidence indicates that lacustrine $\mathrm{CO}_{2}$ production is closely related to IC input (Figure 1). Direct, hydrological input of soil $\mathrm{CO}_{2}$ is assumed to be an important source of lake $\mathrm{CO}_{2}$ (Abril et al., 2014; Maberly et al., 2013; McDonald et al., 2013). On the other hand, dissolved IC (DIC, mainly $\mathrm{HCO}_{3}{ }^{-}$) derived from catchments is thought to be a primary factor in sustaining $\mathrm{CO}_{2}$ emissions in many lakes (Jones et al., 2001; Öquist et al., 2009; Wang et al., 2012, 2015; Weyhenmeyer et al., 2015). These findings are in agreement with the results of a statistical analysis of more than 5,000 lakes reported by Marcé et al. (2015), which showed that $\mathrm{CO}_{2}$ supersaturation in lakes was directly related to carbonate weathering in catchments.

Similar questions concerning carbon sources exist for the OC buried in lake sediments (Downing et al., 2008). If the $O C$ is primarily allochthonous and derived from the terrestrial biosphere, then the lake is not a net sink of carbon because there is no net change in the total amount of $\mathrm{OC}$, just a change in the storage location: catchment soils to lake sediments (Mendonça et al., 2012), unless OC could escape mineralization and is stored in sediments over long time scales (thousands to millions years; Battin et al., 2009; Cole, 2013). In 
contrast, if the $\mathrm{OC}$ is primarily autochthonous and produced by photosynthesis in lake waters, it should not be included in estimates of terrestrial primary production. In this case, lakes may be a net sink of carbon, depending on the sources of $\mathrm{CO}_{2}$ utilized in photosynthesis.

It is still not easy to accurately assess the relative roles of freshwater ecosystems in local and global carbon budgets (Battin et al., 2009; Cole, 2013), despite advances in global estimates of the fluxes of freshwater $\mathrm{CO}_{2}$ evasion and OC burial (e.g., Dean \& Gorham, 1998; Raymond et al., 2013; Regnier et al., 2013; Tranvik et al., 2009). Duarte and Agusti (1998) suggested that if community respiration exceeds gross primary production (GPP), systems are heterotrophic and thus act as $\mathrm{CO}_{2}$ sources; otherwise, systems are autotrophic and act as $\mathrm{CO}_{2}$ sinks. However, measurements of aquatic ecosystem production are difficult to make in real ecosystems (Hanson et al., 2004). Another, more feasible method of assessing the net effect of lakes is quantifying the balance of gaseous carbon evasion and $\mathrm{OC}$ burial. If $\mathrm{OC}$ burial exceeds carbon evasion, lakes and reservoirs act as net $\mathrm{CO}_{2}$ sinks; otherwise, they act as net $\mathrm{CO}_{2}$ sources (Hanson et al., 2004; Mendonça et al., 2012). However, quantitative comparisons of these carbon phases, with no distinctions made of their sources, may lead to inaccurate conclusions.

More important is that freshwater carbon fluxes are significant and require accurate incorporation into terrestrial carbon budgets. In conventional carbon cycling, outgassing from inland waters is blended with fluxes of terrestrial ecosystem respiration. However, if it is terrestrially sourced $O C$ that is respired by heterotrophs in inland waters releasing $\mathrm{CO}_{2}$, these fluxes should be considered part of terrestrial carbon budgets (Cole et al., 2007). Ecosystem production must be increased from a conventional estimate of 2-3.2 to 4-4.5 Pg C a ${ }^{-1}$ to balance the carbon released (see Aufdenkampe et al., 2011; Battin et al., 2009; Tranvik et al., 2009). Considering the strong and extensive connections between carbon transport from terrestrial to aquatic systems, integrating inland waters into terrestrial carbon cycling has been a widely accepted method to construct a complete carbon budget (Buffam et al., 2011; Christensen et al., 2007; Cole et al., 2007; Jonsson et al., 2007). Butman et al. (2016) were the first to do an integrated assessment of freshwater carbon in terrestrial ecosystem production for the conterminous United States. Such an integration is good for constructing local carbon budgets but may limit our understanding of the roles of lakes due to the bypassing of important details of carbon connections between terrestrial and aquatic systems. In particular, integration methods pay close attention to the transfer of OC that belongs to direct products of ecosystem primary production. The catchments involved in prior integration studies (e.g., Buffam et al., 2011; Christensen et al., 2007; Jonsson et al., 2007) are mostly located in boreal and Arctic/subarctic areas, where OC dominates catchment carbon export. IC is a potential sticking point for this method of integration because IC does not belong to NEP (Chapin et al., 2006; Lovett et al., 2006). Lovett et al. (2006) instead used the concept of net ecosystem exchange, and Chapin et al. (2006) proposed the concept of net ecosystem carbon balance, to differentiate IC from NEP; however, NEP is still the most frequently used term in carbon cycling. Although lake carbon is ultimately derived from atmospheric $\mathrm{CO}_{2}$ fixation in catchment primary production, organic and inorganic pathways (or origins) of carbon transport from terrestrial to aquatic ecosystems (Figure 1) have different turnover rates and residence times, and as such have different influences on local and global carbon cycling. Ignoring these differences could result in miscalculations of local and global carbon budgets.

In this paper, a small karst catchment in southwestern China, with one of the highest values of IC export of atmospheric $\mathrm{CO}_{2}$ in the world due to widely distributed carbonates (Ludwig et al., 2011), was chosen for study to address the influence of terrestrial IC transfer on the integration of catchment-lake carbon budgets. Previously, we estimated $\mathrm{CO}_{2}$ emission fluxes in the small reservoir, Lake Hongfeng, and explored the geochemical processes of aquatic $\mathrm{CO}_{2}$ production from inorganic origins (Wang et al., 2012, 2015). Later, soil $\mathrm{CO}_{2}$ concentrations and emission fluxes in the catchment were also reported (Liu et al., 2012). Catchment weathering rates, NPP, and NEP were also estimated. In this study, aquatic $\mathrm{CO}_{2}$ emissions and carbon input and export fluxes in the catchment were observed again with higher sampling frequency and at more sampling sites. By synthesizing the existing and new data for various carbon phases, we are able to comprehensively compare freshwater carbon fluxes with other vertical and lateral fluxes of OC (GPP, NPP, NEP, and $\mathrm{OC}$ export) and IC (soil $\mathrm{CO}_{2}$ emission, carbonate dissolution by soil $\mathrm{CO}_{2}$, and IC export) in this catchment. Then, we integrated lake carbon fluxes in the context of production, transport, transformation, exchange, and storage (of both $\mathrm{OC}$ and IC) in the catchment from a systems perspective. Finally, we developed a 

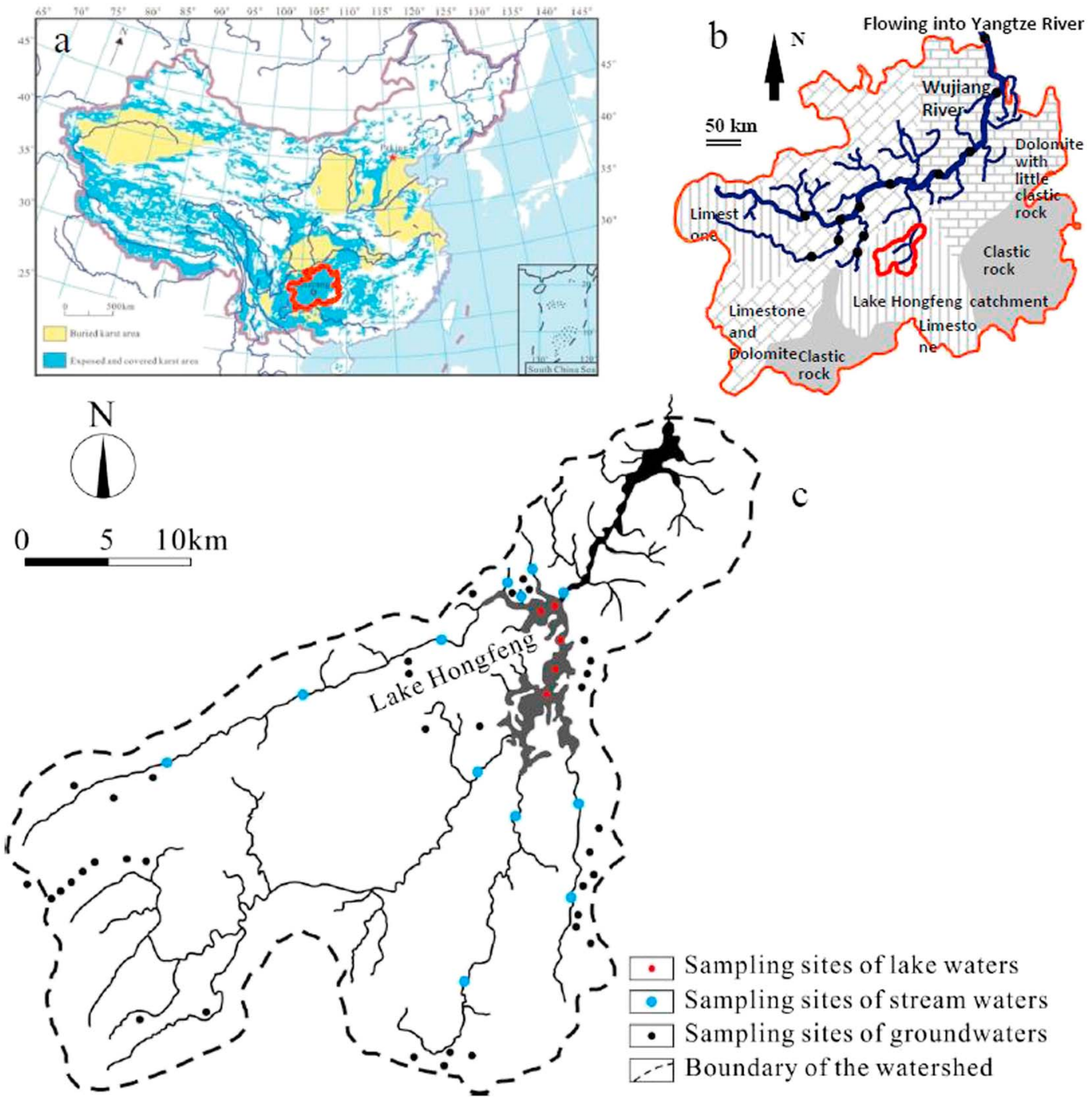

Figure 2. Maps of (a) China, (b) Guizhou province, and the (c) Lake Hongfeng catchment. The distribution of karst in China and the location of Guizhou province (red line) are shown in (a). The Wujiang River, constructed reservoirs (solid circles), the Lake Hongfeng catchment, and the exposed rock types are shown in (b). The sampling sites in the catchment are shown in (c).

method of assessing the significance of lake carbon fluxes to the local carbon budget by considering the origins and coupling of $\mathrm{OC}$ and IC.

\section{Materials and Methods}

The study lake (Lake Hongfeng) and its catchment have been previously described in detail (Wang et al., 2012). Lake Hongfeng $\left(106^{\circ} 19-28^{\prime} \mathrm{E}, 26^{\circ} 26-35^{\prime} \mathrm{N}\right)$ is located in the upper reaches of the Maotiao River, a tributary of the Wujiang River, which is located in the upper reaches of the Yangtze River catchment (Figure 2). It was constructed in 1960 and has a mean water residence time of 0.35 years (Wang et al., 2012). The lake is $16 \mathrm{~km}$ long, with a surface area of $32.2 \mathrm{~km}^{2}$, a catchment area of 1,596 km , a maximum depth of $45 \mathrm{~m}$, an average depth of $9.2 \mathrm{~m}$, and a volume of approximately $0.298 \times 10^{9} \mathrm{~m}^{3}$. Lake Hongfeng is mesotrophic to eutrophic due to input of domestic sewage from surrounding towns, with high concentrations of total nitrogen $\left(0.204 \mathrm{mmol} \mathrm{L}^{-1}\right)$, total phosphorus $\left(1.516 \mu \mathrm{mol} \mathrm{L}^{-1}\right)$, and chlorophyll a $\left(6.2-10.9 \mathrm{mg} \mathrm{m}^{-3}\right.$; Wang et al., 2015).

The Guizhou karst plateau in southwestern China is located in the center of the Southeast Asian Karst Region, where karstification is most developed (Figure 2a). The Lake Hongfeng catchment is located in the center of 
the Guizhou karst plateau (Figure 2b). The catchment is $65 \mathrm{~km}$ long and $17 \mathrm{~km}$ wide, with a southwest to northeast orientation, and an elevation range of 700-1,765 $\mathrm{m}$ above msl. Permian and Triassic age limestones and dolomites dominate the bedrock here (Figure 2b). The catchment is characterized by well-developed karst landforms, steep-sloped valleys, and gorges and is sparsely vegetated (mainly with shrubs and limited broadleaf and coniferous forests). A subtropical, monsoon climate prevails here, with a mean annual temperature of $14{ }^{\circ} \mathrm{C}$, and mean annual precipitation of $1,195 \mathrm{~mm}$.

Lake Hongfeng and its surrounding streams, springs, and headwaters were sampled seasonally from 2001 to 2002 and bimonthly in 2004 (Wang et al., 2015). In 2013, lake and stream waters were again collected at these sites with higher sampling frequency (monthly to semimonthly), sampling of spring water in the catchment was extended from 12 to 36 sites (Figure 2c), and sampling frequency was increased from 1 to 10 times (see Appendix Tables S1, S2, and S3 in the supporting information), with the overall objective of reducing uncertainties in the results. Sample analysis methods were described in Wang et al. (2015). $\mathrm{pCO}_{2}$ was calculated from $\mathrm{HCO}_{3}{ }^{-}, \mathrm{pH}$, the reaction constant between $\mathrm{HCO}_{3}{ }^{-}$and $\mathrm{CO}_{2}(\mathrm{aq})$, and Henry's law constant for $\mathrm{CO}_{2}$ (Wallin et al., 2010; Wang et al., 2015).

The exchange flux $(F)$ of $\mathrm{CO}_{2}$ through the water-air interface was estimated by a molecular diffusion model:

$$
F=k \times \Delta C
$$

where $k=$ the gas exchange rate $\left(0.75 \mathrm{~m} \mathrm{~d}^{-1}\right.$ for lake surface and $1.9 \mathrm{~m} \mathrm{~d}^{-1}$ for stream surface; Cole et al., 1994; Cole \& Caraco, 2001) and $\Delta C=$ the difference of gas concentration across the interface. Groundwater $\mathrm{CO}_{2}$ evasion was estimated by multiplying the $\mathrm{CO}_{2}$ concentration difference between spring water and river water by the mean annual discharge. Input and export fluxes of carbon species into and out of the lake were estimated by multiplying riverine carbon concentrations by discharge. Export flux of $\mathrm{HCO}_{3}{ }^{-}$out of the catchment was estimated by multiplying the $\mathrm{HCO}_{3}{ }^{-}$concentration in the groundwater by mean annual discharge. $\mathrm{HCO}_{3}{ }^{-}$in groundwater is mainly produced by the weathering of carbonate by soil $\mathrm{CO}_{2}$ :

$$
\mathrm{CaCO}_{3}+\mathrm{CO}_{2}+\mathrm{H}_{2} \mathrm{O}=\mathrm{Ca}^{2+}+2 \mathrm{HCO}_{3}{ }^{-}
$$

Half of the $\mathrm{HCO}_{3}{ }^{-}$in equation (2) is from soil $\mathrm{CO}_{2}$, and half is from carbonate. On the other hand, sulfuric and

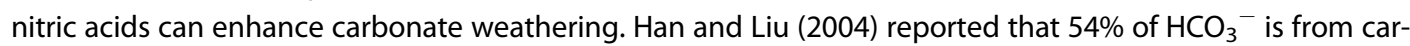
bonate, and $46 \%$ is from soil $\mathrm{CO}_{2}$. We estimated the $\mathrm{CO}_{2}$ consumption flux in carbonate dissolution using the empirical ratio 54/46. The deposition and burial fluxes (Fs) of carbon in the sediments were calculated using

$$
\mathrm{Fs}=a \times \mathrm{Cc}
$$

where $a=$ sediment mass accumulation rates and $\mathrm{Cc}=$ carbon concentrations in sediments in the upper $2 \mathrm{~cm}$ (for deposition flux) or below $30 \mathrm{~cm}$ (for burial flux; see Appendix Table S4). The emission rate of soil $\mathrm{CO}_{2}$ was measured monthly from June 2006 to May 2007, at 10 sampling plots in the catchment using a dark static flux chamber (Liu et al., 2012). NPP and NEP were compiled from published data (J. Cao et al., 2011; M. Cao et al., 2003; Dong \& Ni, 2011; Gu et al., 2007; Ke et al., 2003; Liu, 2017). GPP, AR, and HR were estimated using

$$
\begin{aligned}
& \mathrm{NPP}=\mathrm{GPP}-\mathrm{AR} \\
& \mathrm{NEP}=\mathrm{NPP}-\mathrm{HR}
\end{aligned}
$$

All results are expressed with average \pm standard deviation.

\section{Results and Discussion}

\subsection{Aquatic $\mathrm{CO}_{2}$ Emission and $\mathrm{OC}$ Burial in the Catchment}

Partial pressures of $\mathrm{CO}_{2}$ in the surface lake water and emission flux of $\mathrm{CO}_{2}$ at the lake water-air interface showed clear seasonal patterns, according to the observations that have made with higher sampling frequency at more sampling sites in 2013 (Figure 3) relative to the previous study (Wang et al., 2015). In summer and fall, the surface lake water was undersaturated with respect to atmospheric $\mathrm{CO}_{2}$ owing to heavy consumption of $\mathrm{CO}_{2}$ by algal photosynthesis. Therefore, it absorbed $\mathrm{CO}_{2}$ from the atmosphere and acted as a carbon sink. In winter and early spring, the lake water was supersaturated in $\mathrm{CO}_{2}$ with high $\mathrm{pCO}_{2}$ ranging from 1,000 to $2,000 \mu$ atm and emitted more $\mathrm{CO}_{2}$ into the atmosphere, acting as a carbon source (Figure 3). In comparison, variations of $\mathrm{pCO}_{2}$ displayed some irregular patterns in the previous observation that had a 


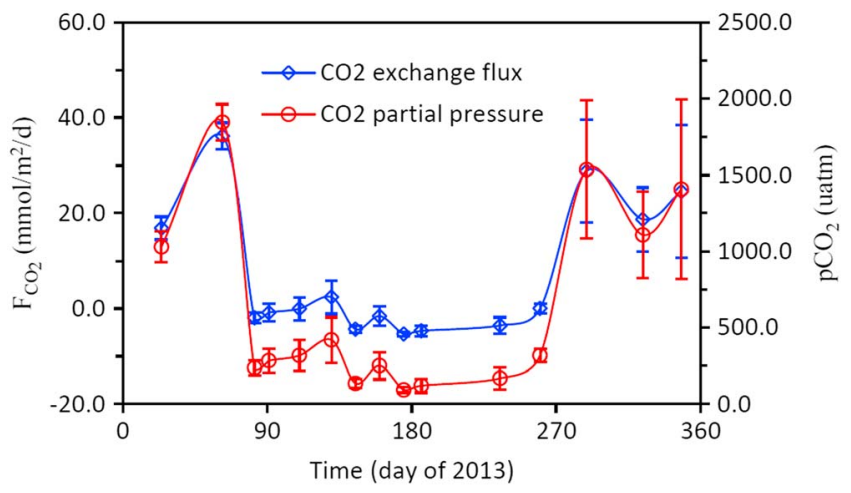

Figure 3. Seasonal variations of $\mathrm{CO}_{2}$ emission fluxes and $\mathrm{pCO}_{2}$ in lake surface waters, 2013. low sampling frequency (Wang et al., 2015). For example, exceptionally high $\mathrm{pCO}_{2}$ of up to $5,000 \mu \mathrm{atm}$ occurred, and sometimes the lake water was under saturated in $\mathrm{CO}_{2}$ in winter when the lake was vertically mixed (see Wang et al., 2015). As a whole, the seasonal pattern of $\mathrm{CO}_{2}$ emissions that was observed in this time is in accord with the mesotrophic-eutrophic status of the lake. On the other hand, the seasonal pattern showed that the conversion of the lake between acting as a carbon source and sink could be finished in a short time (Figure 3), indicating that high sampling frequency is essential for acquiring convincing results. Annual averages of emission fluxes of $\mathrm{CO}_{2}$ at the lake water-air interface ranged from 7.0 to $19.0 \mathrm{mmol} \mathrm{m} \mathrm{m}^{-2} \mathrm{~d}^{-1}$, with no clear interannual variation trends (Table 1). The overall average of the means is $11.5 \pm 2.6 \mathrm{mmol} \mathrm{m}^{-2} \mathrm{~d}^{-1}$ (Table 1), which is slightly lower than the mean, global value (16.2 mmol $\mathrm{m}^{-2} \mathrm{~d}^{-1}$, Cole et al., 1994). This flux is equal to $1.0 \pm 0.2 \mathrm{~g} \mathrm{C} \mathrm{m}^{-2} \mathrm{a}^{-1}$ when expressed considering catchment area. The average of $\mathrm{pCO}_{2}$ values $(3,725.1 \pm 1,938.1)$ at seven catchment stream sampling sites observed in 2001-2001 were consistent with those from rivers from other regions of the world (Butman \& Raymond, 2011; Cole \& Caraco, 2001; Raymond et al., 2013). The average decreased to 2,730.7 $\pm 473.2 \mu$ atm in 2013 (Table 1). Assuming that stream surface area is about $0.19 \%$ of the catchment surface, like other low-order streams in headwater areas (Wallin et al., 2013), riverine $\mathrm{CO}_{2}$ evasion could be estimated to be $1.5 \pm 0.2 \mathrm{~g} \mathrm{C} \mathrm{m}^{-2} \mathrm{a}^{-1}$, which is slightly lower than the results from a boreal headwater catchment $\left(1.8 \mathrm{~g} \mathrm{C} \mathrm{m}^{-2} \mathrm{a}^{-1}\right)$ reported by Leith et al. (2015) but much lower than the value $\left(5.0 \pm 1.8 \mathrm{~g} \mathrm{C} \mathrm{m}^{-2} \mathrm{a}^{-1}\right)$ in DOC-rich streams in northern Sweden documented by Wallin et al. (2013). Including groundwater $\mathrm{CO}_{2}$ degassing of $1.9 \pm 0.1 \mathrm{~g} \mathrm{C} \mathrm{m}^{-2} \mathrm{a}^{-1}$, total $\mathrm{CO}_{2}$ evasion from the aquatic environments in this catchment was as high as $4.4 \mathrm{~g} \mathrm{C} \mathrm{m}^{-2} \mathrm{a}^{-1}$, of which the lake accounts for $23 \%$, river water for $34 \%$, and groundwater for $43 \%$.

The inorganic and OC concentrations in lake sediments decreased with depth (Figure 4, similar to the results of Wang et al. (2015). Using the sediment mass accumulation rate of $0.17 \mathrm{~g} \mathrm{~cm}^{-2} \mathrm{a}^{-1}$ (Wan et al., 1990) and the $\mathrm{OC}$ concentrations in the sediment, it was estimated that $\mathrm{OC}$ was delivered to the sediment-water interface at a rate of approximately $29.7 \pm 7.3 \mathrm{mmol} \mathrm{C} \mathrm{m} \mathrm{m}^{-2} \mathrm{~d}^{-1}$, of which $\sim 69 \%$ was remineralized during burial (diagenesis), leaving $9.9 \pm 1.6 \mathrm{mmol} \mathrm{C} \mathrm{m} \mathrm{C}^{-2} \mathrm{~d}^{-1}$ to be stored in the sediment (Table 1). The flux was $0.9 \pm 0.2 \mathrm{~g} \mathrm{C} \mathrm{m}^{-2} \mathrm{a}^{-1}$ as expressed considering catchment area. Organic $\mathrm{N}$ concentrations decreased, and C:N ratios increased with depth in lake floor sediments (Figure 4) due to organic matter decomposition, during which $\mathrm{CO}_{2}$ was released and further dissolved carbonate. As a result, IC concentrations sharply decreased (Figure 4), and $\mathrm{HCO}_{3}{ }^{-}$had high concentrations in sediment pore waters, and thus could diffuse into overlying lake water (Wu et al., 1997).

\subsection{Terrestrial $\mathrm{OC}$ and IC Fluxes in Relation to $\mathrm{CO}_{2}$ Exchange}

Net primary production in this karst catchment is relatively low, according to the compiled data. Estimates of NPP here varied, as investigators utilized different methods (Table 2). According to Ke et al.'s (2003) results using the Carnegie Ames Stanford Approach (CASA) model, average NPP in the southwestern part of the Yangtze River catchment (1981-2000) was $262 \mathrm{~g} \mathrm{C} \mathrm{m}^{-2} \mathrm{a}^{-1}$ (Table 2). Gu et al. (2007) used the Atmosphere-Vegetation Interaction Model to model NPP in the same area and reported $417 \mathrm{~g} \mathrm{C} \mathrm{m}^{-2} \mathrm{a}^{-1}$. Dong and Ni's (2011) results using the CASA model (1999-2003) showed that NPP in Guizhou was $<285 \mathrm{~g} \mathrm{C} \mathrm{m}^{-2} \mathrm{a}^{-1}$. This value is in broad agreement with J. Cao et al.'s (2011) results, showing that NPP from 1991 to 2009 in Guizhou ranged from 194.0 to $268.3 \mathrm{~g} \mathrm{C} \mathrm{m}^{-2} \mathrm{a}^{-1}$ (mean of $227.5 \pm 23.6 \mathrm{~g} \mathrm{C} \mathrm{m}^{-2} \mathrm{a}^{-1}$ ). Liu's (2017) result using the Lund-Potsdam-Jena Dynamics Global Vegetation Model suggested that the average NPP of vegetation in Guizhou reached $737.8 \mathrm{~g} \mathrm{C} \mathrm{m}^{-2} \mathrm{a}^{-1}$. It is interesting to note that Ke et al. (2003), Dong and Ni (2011), and J. Cao et al. (2011) all used the process-based CASA model (Table 2) and reported similar, low results for NPP (194.5-285 $\mathrm{g} \mathrm{C} \mathrm{m}^{-2} \mathrm{a}^{-1}$ ). In comparison, Gu et al. (2007), Liu (2017), and Wang, Yang, and Wang (2007) used land and eco-physiology feedback-based vegetation models and meteorological data to model NPP and all reported higher values $\left(417.0-737.8 \mathrm{~g} \mathrm{C} \mathrm{m}^{-2} \mathrm{a}^{-1}\right)$. Given that vegetation in this catchment is sparse and shrub-dominated, the results from the eco-physiology-based vegetation models 
Table 1

Carbon Exchange Fluxes in the Lake Hongfeng Catchment

\begin{tabular}{|c|c|c|c|c|c|c|c|}
\hline \multirow[b]{2}{*}{ Processes } & \multirow[b]{2}{*}{$\begin{array}{c}\text { Compartment } \\
\text { /C types }\end{array}$} & \multirow[b]{2}{*}{ Time } & \multirow[b]{2}{*}{$\begin{array}{l}\mathrm{pCO}_{2}(\mu \mathrm{atm}) / \mathrm{OC} \\
\text { or IC contents (\%) }\end{array}$} & \multicolumn{2}{|c|}{ Exchange fluxes of carbon } & \multirow[b]{2}{*}{$\begin{array}{l}\text { Sampling } \\
\text { frequencies }\end{array}$} & \multirow[b]{2}{*}{ References } \\
\hline & & & & $\begin{array}{c}\text { Mmol m } \mathrm{m}^{-2} \mathrm{~d}^{-1} \\
\text { per lake surface } \\
\text { area }\end{array}$ & 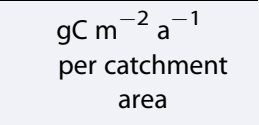 & & \\
\hline \multirow{11}{*}{$\begin{array}{r}\text { Aquatic } \mathrm{CO}_{2} \\
\text { emissions }\end{array}$} & Surface & 2001 & $1,185.3 \pm 557.1$ & $19.0 \pm 13.7$ & $1.7 \pm 1.2$ & 5 Times at 3 Sites & Wang et al. (2015) \\
\hline & lake water & 2002 & $675.4 \pm 254.0$ & $7.6 \pm 12.8$ & $0.7 \pm 1.1$ & 2 Times at 3 Sites & Wang et al. (2015) \\
\hline & & 2004 & $876.7 \pm 361.7$ & $12.2 \pm 8.6$ & $1.1 \pm 0.8$ & 6 Times at 4 Sites & Wang et al. (2015) \\
\hline & & 2013 & $617.9 \pm 275.0$ & $7.0 \pm 6.5$ & $0.6 \pm 0.6$ & 15 Times at 5 Sites & This study \\
\hline & & Average & $838.8 \pm 118.5$ & $11.5 \pm 2.6$ & $1.0 \pm 0.2$ & & \\
\hline & River & 2002 & $3,725.0 \pm 1,938.1$ & $201.5 \pm 114.5$ & $1.7 \pm 1.0$ & 4 Times at 7 Sites & Wang et al. (2015) \\
\hline & & 2013 & $2,730.7 \pm 473.2$ & $142.8 \pm 28.0$ & $1.2 \pm 0.2$ & 10 Times at 12 Sites & This study \\
\hline & & Average & $3,086.9 \pm 232.9$ & $172.2 \pm 19.2$ & $1.5 \pm 0.2$ & & \\
\hline & Groundwater & 2002 & $10,207.0 \pm 7,749.0$ & & $1.9 \pm 1.8$ & 1 Time at 12 Sites & Wang et al. (2015) \\
\hline & & 2013 & $8,798.4 \pm 1,046.7$ & & $1.8 \pm 0.2$ & 10 Times at 36 Sites & This study \\
\hline & & Average & $9,502.7 \pm 996.0$ & & $1.9 \pm 0.1$ & & \\
\hline \multirow{16}{*}{$\begin{array}{l}\text { Carbon exchange } \\
\text { at the sediment- } \\
\text { water interface }\end{array}$} & OC deposition & January 2002 & $11.1 \pm 0.8$ & $43.4 \pm 2.3$ & $3.8 \pm 0.3$ & & Wang et al. (2015) \\
\hline & & August 2002 & $6.9 \pm 0.8$ & $27.4 \pm 2.3$ & $2.4 \pm 0.3$ & & Wang et al. (2015) \\
\hline & & May 2015 & $4.5 \pm 0.2$ & $18.3 \pm 0.1$ & $1.5 \pm 0.1$ & & This study \\
\hline & & Average & $5.7 \pm 1.7$ & $29.7 \pm 7.3$ & $2.6 \pm 1.1$ & & \\
\hline & OC burial & January 2002 & $2.9 \pm 0.1$ & $11.4 \pm 0.5$ & $1.0 \pm 0.03$ & & Wang et al. (2015) \\
\hline & & August 2002 & $2.9 \pm 0.4$ & $11.4 \pm 2.3$ & $1.0 \pm 0.1$ & & Wang et al. (2015) \\
\hline & & May 2015 & $2.0 \pm 0.3$ & $6.8 \pm 2.3$ & $0.7 \pm 0.1$ & & This study \\
\hline & & Average & $2.6 \pm 0.5$ & $9.9 \pm 3.2$ & $0.9 \pm 0.2$ & & \\
\hline & IC deposition & January 2002 & $8.2 \pm 5.5$ & $32.0 \pm 20.5$ & $2.8 \pm 1.9$ & & Wang et al. (2015) \\
\hline & & August 2002 & $10.9 \pm 0.6$ & $43.4 \pm 2.3$ & $3.7 \pm 0.2$ & & Wang et al. (2015) \\
\hline & & May 2015 & $3.9 \pm 0.1$ & $16.0 \pm 0.5$ & $1.3 \pm 0.03$ & & This study \\
\hline & & Average & $7.4 \pm 4.9$ & $30.5 \pm 7.6$ & $2.6 \pm 1.2$ & & \\
\hline & IC burial & January 2002 & $1.7 \pm 0.3$ & $6.8 \pm 2.3$ & $0.6 \pm 0.1$ & & Wang et al. (2015) \\
\hline & & August 2002 & 1.4 & 4.6 & 0.5 & & Wang et al. (2015) \\
\hline & & May 2015 & $1.4 \pm 0.1$ & $4.6 \pm 0.5$ & $0.5 \pm 0.03$ & & This study \\
\hline & & Average & $1.5 \pm 0.2$ & $5.3 \pm 0.8$ & $0.5 \pm 0.1$ & & \\
\hline \multirow{6}{*}{$\begin{array}{l}\text { Terrestrial } \\
\text { carbon } \\
\text { exchanges }\end{array}$} & NPP & & & & 204.6 to 274.3 & & See Table 2 \\
\hline & NEP & & & & $-8(0$ to -20$)$ & & See Table 2 \\
\hline & Soil $\mathrm{CO}_{2}$ efflux & $2006 / 2007$ & & & $1,392.0 \pm 122.6$ & 12 Times at 10 Sites & Liu et al. (2012) \\
\hline & $\mathrm{CO}_{2}$ & 2001 & & & 12.6 & & Wang et al. (2015) \\
\hline & consumption & 2013 & & & 10.5 & & This study \\
\hline & $\begin{array}{l}\text { in carbonate } \\
\text { erosion }\end{array}$ & Average & & & $11.6 \pm 1.5$ & & \\
\hline \multirow{14}{*}{$\begin{array}{l}\text { Carbon input } \\
\text { into the lake } \\
\text { from the } \\
\text { catchment }\end{array}$} & $\mathrm{CO}_{2}$ & 2001 & & & 0.8 & & Wang et al. (2015) \\
\hline & & 2013 & & & $0.40 .6 \pm 0.13$ & & This study \\
\hline & & Average & & & & & \\
\hline & & 2001 & & & $\begin{array}{c}18.0 \text { (8.4 from } \\
\left.\text { soil } \mathrm{CO}_{2}\right)\end{array}$ & & Wang et al. (2015) \\
\hline & $\mathrm{HCO}_{3}{ }^{-}$ & 2013 & & & $\begin{array}{c}15.0(6.9 \text { from } \\
\left.\text { soil } \mathrm{CO}_{2}\right)\end{array}$ & & This study \\
\hline & & Average & & & $\begin{array}{c}16.5 \pm 2.1(7.7 \pm 1.1 \\
\left.\text { from soil } \mathrm{CO}_{2}\right)\end{array}$ & & \\
\hline & & 2001 & & & 0.15 & & Wang et al. (2015) \\
\hline & $\mathrm{CO}_{3}{ }^{2-}$ & 2013 & & & 0.15 & & This study \\
\hline & & Average & & & 0.15 & & \\
\hline & DIC & 2001 & & & 19.0 & & Wang et al. (2015) \\
\hline & & 2013 & & & 15.5 & & This study \\
\hline & & Average & & & $17.3 \pm 2.5$ & & \\
\hline & $\mathrm{DOC}$ & 2001 & & & 0.9 & & Wang et al. (2015) \\
\hline & POC & 2001 & & & 0.2 & & Wang et al. (2015) \\
\hline \multirow{5}{*}{$\begin{array}{l}\text { Lake carbon export } \\
\text { downstream }\end{array}$} & DIC & 2001 & & & 16.2 & & Wang et al. (2015) \\
\hline & & 2013 & & & 14.4 & & This study \\
\hline & & Average & & & $15.3 \pm 1.3$ & & \\
\hline & $\mathrm{DOC}$ & 2001 & & & 1.4 & & Wang et al. (2015) \\
\hline & POC & 2001 & & & 0.15 & & Wang et al. (2015) \\
\hline
\end{tabular}



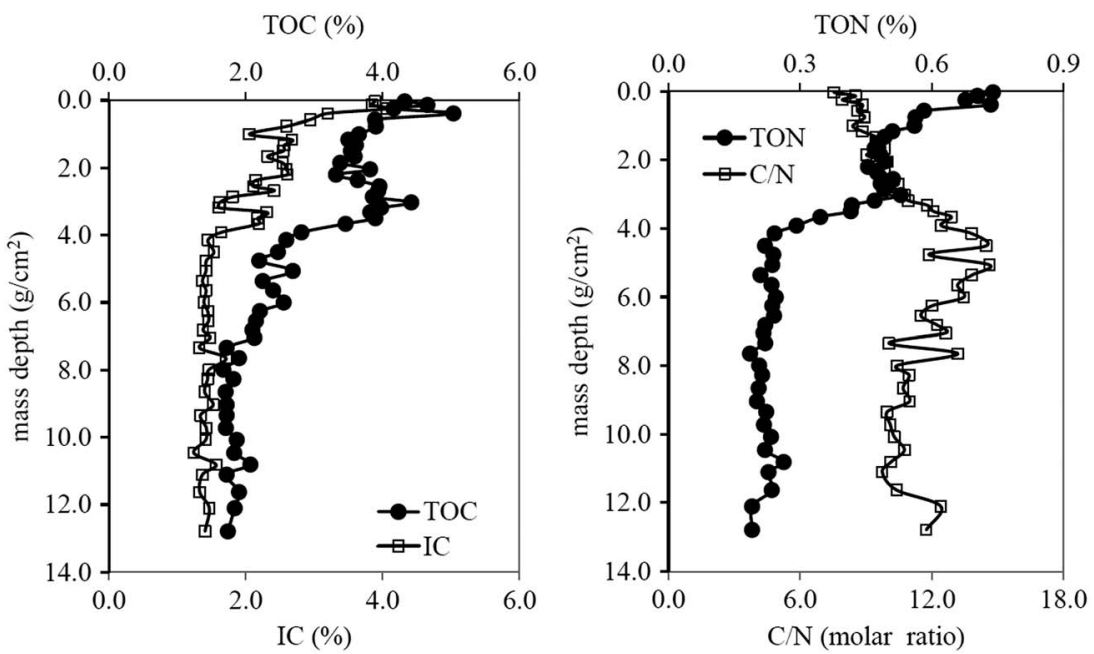

Figure 4. Profiles of total organic carbon, inorganic carbon, total organic nitrogen, and C:N ratios in lake floor sediments.

likely reflect the NPP of vegetation and forest ecosystems but overestimate overall NPP for the entire catchment. Thus, we adopted the confidence interval (204.6-274.3 $\left.\mathrm{g} \mathrm{C} \mathrm{m}^{-2} \mathrm{a}^{-1}\right)$ from the CASA model at $95 \%$ confidence level as the most likely range of NPP for this catchment (Table 1). As a whole, these values are relatively low. In contrast, modeling results show that the relatively high temperature and precipitation here produced high respiration rates in the catchment (J. Cao et al., 2011; Liu, 2017). As a result, NEP in the area was consistently negative $\left(0\right.$ to $\left.-20 \mathrm{~g} \mathrm{C} \mathrm{m}^{-2} \mathrm{a}^{-1}\right)$ as documented by M. Cao et al. (2003). This was confirmed by the modeling results reported by Liu (2017), which indicate that NEP is negative in $85 \%$ of the Guizhou Province, with an average of $-8 \mathrm{~g} \mathrm{C} \mathrm{m}^{-2} \mathrm{a}^{-1}$ (Table 1).

Comparatively, soil $\mathrm{CO}_{2}$ efflux in this catchment is high. The vertical $\mathrm{CO}_{2}$ efflux from soils reached an average value of 1,392 $\pm 122.6 \mathrm{~g} \mathrm{C} \mathrm{m}^{-2} \mathrm{a}^{-1}$ (Liu et al., 2012). This value is in agreement with J. Cao et al.'s (2011) observation showing that soil respiration in Guizhou was $1,487.7 \pm 63.3 \mathrm{~g} \mathrm{C} \mathrm{m}^{-2} \mathrm{a}^{-1}$. These emission rates of soil $\mathrm{CO}_{2}$ in carbonate areas are similar to results from noncarbonate areas of China, in spite of the relatively low NPP. Mo et al. (2005) gauged the soil $\mathrm{CO}_{2}$ efflux in evergreen broadleaf forest, pine forest, and pine and broadleaf mixed forest in the subtropical, monsoonal Dinghushan area $\left(23^{\circ} 10^{\prime} \mathrm{N}, 112^{\circ} 34^{\prime} \mathrm{E}\right)$ in southern China at 1,550, 1,419, and 1,103 $\mathrm{g} \mathrm{C} \mathrm{m}^{-2} \mathrm{a}^{-1}$, respectively. According to estimates of NPP and NEP (Table 2) and equation (5), HR in this catchment should range from 200 to $290 \mathrm{~g} \mathrm{C} \mathrm{m}^{-2} \mathrm{a}^{-1}$. If soil $\mathrm{CO}_{2}$ is further assumed only to originate from autotrophic and $H R$, and not from abiological sources, AR should range between 1,100 and $1,200 \mathrm{~g} \mathrm{C} \mathrm{m}^{-2} \mathrm{a}^{-1}$. These estimates indicate that $\sim 80 \%$ of soil $\mathrm{CO}_{2}$ was derived from root respiration, and the remaining $20 \%$ was derived from heterotrophic decomposition of soil organic matter. Even though the abiological contribution to soil $\mathrm{CO}_{2}$ is taken into account (15-35\%; Wang et al., 2015), the amount of $\mathrm{CO}_{2}$ derived from root respiration still surpassed that from HR. It must be noted that the simple estimates of contributions of heterotrophic and $\mathrm{AR}$ to soil $\mathrm{CO}_{2}$ presented here contain large errors, since partitioning of soil $\mathrm{CO}_{2}$ between heterotrophic and AR is a complicated task (see Hanson et al., 2000;

Table 2

A Comparison of the Compiled NPP and NEP Data

\begin{tabular}{|c|c|c|c|c|c|}
\hline References & Region of modeling & Period of modeling & Model & $\operatorname{NPP}\left(\mathrm{gC} / \mathrm{m}^{2} / \mathrm{a}\right)$ & $\operatorname{NEP}\left(\mathrm{gC} / \mathrm{m}^{2} / \mathrm{a}\right)$ \\
\hline Ke et al. (2003) & The Yangtze Basin & $1981-2000$ & CASA & 262 & \\
\hline Dong and $\mathrm{Ni}$ (2011) & Guizhou & 1999-2003 & CASA & $<285$ & \\
\hline J. Cao et al. (2011) & Guizhou & $1991-2009$ & CASA & $227.5 \pm 23.6(194.0-268.3)$ & \\
\hline Gu et al. (2007) & Southwest China & $1981-2000$ & AVIM2 & 417.0 & \\
\hline Wang et al. (2007) & Guizhou & 2001 & Light use efficiency model & 407.2 & \\
\hline M. Cao et al. (2003) & Guizhou & 1988-1998 & CEVSA and GLO-PEM & & 0 to -20 \\
\hline Liu (2017) & Guizhou & $2000-2010$ & LPJ-karst & 737.8 & -8 \\
\hline
\end{tabular}




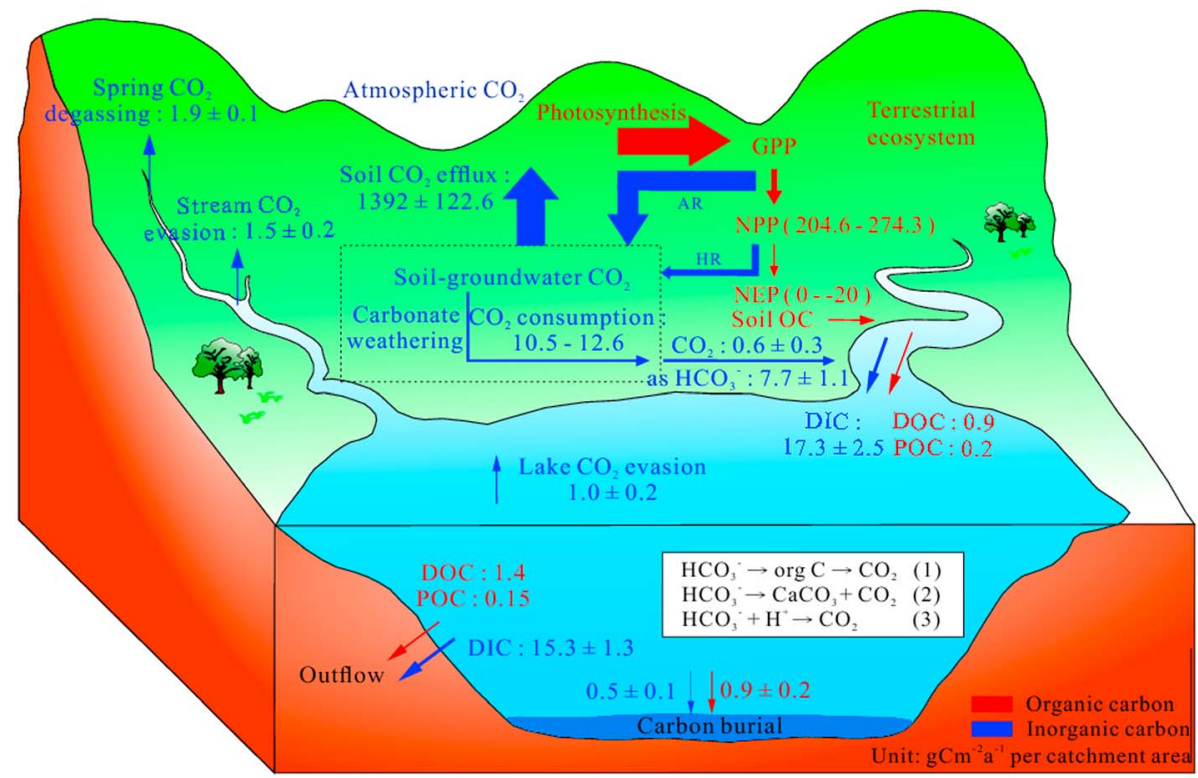

Figure 5. Pathways and vertical and lateral fluxes of organic carbon and inorganic carbon transfer in the soil (vegetation)—carbonate-water systems in the Lake Hongfeng catchment. Size of arrows reflects relative magnitudes (for data see Table 1).

Kuzyakov, 2006). Generally, the contribution of root respiration to soil $\mathrm{CO}_{2}$ emissions varies over a large range $(<10 \%$ to $>90 \%)$, with an overall mean of $48 \%$ as reported by Hanson et al. (2000), who compiled data from 50 studies covering large areas of the globe. Ding et al. (2010) found that the contribution of root respiration to soil $\mathrm{CO}_{2}$ emissions averaged $>80 \%$ in densely vegetated parts of the evergreen broad lead forest, and the contribution was $>90 \%$ in the upper $20 \mathrm{~cm}$ of soil, and decreased to $32 \%$ below $20 \mathrm{~cm}$ at sparsely vegetated sites in the Dinghushan area in southern China, geographically near to the study area. The phenomenon reported here, that root respiration contributed a large proportion of soil $\mathrm{CO}_{2}$ in the catchment, is consistent with the observation that plants in karst areas tend to allocate more biomass in roots (Ni et al., 2015).

The lateral flux of soil $\mathrm{CO}_{2}$ export into streams in this catchment is a small proportion of the soil $\mathrm{CO}_{2}$ budget, $<1 \%$ of the vertical emission of soil $\mathrm{CO}_{2}$ to the atmosphere. This flux consists of two parts: free $\mathrm{CO}_{2}$ in waters and the $\mathrm{HCO}_{3}{ }^{-}$that is produced by chemical weathering of rock by soil $\mathrm{CO}_{2}$ (excluding carbon from carbonate). The latter has been estimated to be $8.4 \mathrm{~g} \mathrm{C} \mathrm{m}^{-2} \mathrm{a}^{-1}$ in 2001 (Wang et al., 2012) and $6.9 \mathrm{~g} \mathrm{C} \mathrm{m}^{-2} \mathrm{a}^{-1}$ in 2013 (Table 1), using catchment stream discharge and $\mathrm{HCO}_{3}{ }^{-}$concentrations. In comparison, J. Cao et al. (2011) determined the mass loss of carbonate tablets that were placed into soils in the field to gauge the rate of carbonate dissolution at $13.8 \mathrm{~g} \mathrm{C} \mathrm{m}^{-2} \mathrm{a}^{-1}$ in the Pearl River catchment of China, which geographically borders the study site. It is understandable that our results are lower than those from J. Cao et al.'s (2011) experiment because carbonate precipitation and $\mathrm{CO}_{2}$ evasion, likely as well photosynthesis, reduced DIC concentrations from $3.99 \pm 1.17 \mathrm{mmol} \mathrm{L}^{-1}(n=318)$ in groundwater to $2.64 \pm 0.80 \mathrm{mmol} \mathrm{L}^{-1}(n=115)$ in streams. It could be concluded that the flux of soil $\mathrm{CO}_{2}$ consumption in the catchment due to carbonate erosion might range from 10.5 to $12.6 \mathrm{~g} \mathrm{C} \mathrm{m}^{-2} \mathrm{a}^{-1}$ (Table 1). Gombert (2002) gave an average global karst dissolution rate of $10.8 \mathrm{~g} \mathrm{C} \mathrm{m}^{-2} \mathrm{a}^{-1}$. The results within Guizhou are slightly larger than the global average, due likely to the wet and hot climate.

\subsection{Process-Based Integration Shows That the Lake $\mathrm{CO}_{2}$ Originates From Soil $\mathrm{CO}_{2}$ in the Catchment}

By synthesizing existing and new data (Table 1), the catchment-scale mass balance of carbon, coupling with $\mathrm{NPP}$, NEP, soil $\mathrm{CO}_{2}$ emissions, carbonate dissolution by soil $\mathrm{CO}_{2}$, and aquatic $\mathrm{CO}_{2}$ emissions, was constructed (Figure 5). The lake received a considerable amount of carbon input from the catchment, of which IC was $17.3 \pm 2.5 \mathrm{~g} \mathrm{C} \mathrm{m}^{-2} \mathrm{a}^{-1}$ and $\mathrm{OC}$ was $1.1 \mathrm{~g} \mathrm{C} \mathrm{m}^{-2} \mathrm{a}^{-1}$ (Figure 5). Catchment carbon (hereinafter excluding carbon from carbonate) export from terrestrial to aquatic systems in the form of DIC species ( $\left.8.3 \mathrm{~g} \mathrm{C} \mathrm{m}^{-2} \mathrm{a}^{-1}\right)$ is about 8 times as much as in the form of OC species $\left(1.1 \mathrm{~g} \mathrm{C} \mathrm{m}^{-2} \mathrm{a}^{-1}\right)$. Such high 
export loading of DIC from this catchment undoubtedly results from chemical weathering of carbonate. Due to high dissolution rates, carbonate dissolution rapidly and constantly consumes soil $\mathrm{CO}_{2}$ to form $\mathrm{HCO}_{3}{ }^{-}$and exports $\mathrm{HCO}_{3}{ }^{-}$to streams, and then to the lake (Figure 5). By this mechanism, carbonate dissolution could markedly accelerate the processes of catchment carbon transfer from terrestrial to aquatic ecosystems and thus strengthen the IC connection between the two systems. The export of DIC takes part in carbon cycling in the lake, and then a portion of the DIC is exported downstream, and another portion is released to the atmosphere as $\mathrm{CO}_{2}$, or is converted into $\mathrm{OC}$ that is buried in the sediment (Figure 5), highlighting the significance of catchment carbonate dissolution in terms of terrestrial carbon export.

At the catchment scale, the lake is a net producer of OC. Comparison between lake $\mathrm{CO}_{2}$ evasion and OC input fluxes indicates that $\mathrm{OC}$ provided by the catchment is not likely the primary source of lake $\mathrm{CO}_{2}$. $\mathrm{DOC}$ export from the catchment $\left(0.9 \mathrm{~g} \mathrm{C} \mathrm{m}^{-2} \mathrm{a}^{-1}\right)$ was much larger than POC $\left(0.2 \mathrm{~g} \mathrm{C} \mathrm{m}^{-2} \mathrm{a}^{-1}\right)$. However, DOC concentrations were low in stream waters, spring waters, and groundwater in the catchment (Wang et al., 2012). As a result, the low export load of OC cannot maintain the carbon emission and carbon budget of the lake. In comparison, the amount of $\mathrm{DOC}$ provided to the lake was slightly less than the lake $\mathrm{CO}_{2}$ evasion and was also less than the downstream export of the lake $\left(1.55 \mathrm{~g} \mathrm{C} \mathrm{m}^{-2} \mathrm{a}^{-1}\right)$. Considering OC burial of $0.9 \pm 0.2 \mathrm{~g} \mathrm{C} \mathrm{m}^{-2} \mathrm{a}^{-1}$ in the sediment, the lake is actually a net producer of OC, while simultaneously also emitting considerable amounts of $\mathrm{CO}_{2}$ to the atmosphere.

Dissolved IC influx sustains gaseous $\mathrm{CO}_{2}$ evasion and $\mathrm{OC}$ burial in the lake. Mass balance shows that the difference between DIC input and export in the lake $\left(2.0 \mathrm{~g} \mathrm{C} \mathrm{m}^{-2} \mathrm{a}^{-1}\right)$ approximately equals the total amount of $\mathrm{CO}_{2}$ emitted $\left(1.0 \mathrm{~g} \mathrm{C} \mathrm{m}^{-2} \mathrm{a}^{-1}\right)$, plus $\mathrm{OC}$ buried in the sediment $\left(0.9 \mathrm{~g} \mathrm{C} \mathrm{m}^{-2} \mathrm{a}^{-1}\right)$, and the difference between OC export and input $\left(0.45 \mathrm{~g} \mathrm{C} \mathrm{m}^{-2} \mathrm{a}^{-1}\right.$; Figure 5). Small differences between the total carbon input to and exported from the lake are likely a product of data uncertainty and/or due to some carbon input that was not considered. As a whole, DIC input is likely a crucial factor in supporting $\mathrm{CO}_{2}$ emission and $\mathrm{OC}$ burial in the lake. In a previous study, we identified three geochemical processes in the lake (Wang et al., 2015), by which $\mathrm{HCO}_{3}{ }^{-}$could be converted to $\mathrm{CO}_{2}$ (equations (1)-(3) in Figure 5). In fact, there have been many studies over the past decade (Finlay et al., 2009; Jones et al., 2001; Marcé et al., 2015; McDonald et al., 2013; Weyhenmeyer et al., 2015) which argued that a portion of lake $\mathrm{CO}_{2}$ was derived from catchment DIC input. As shown in Figure 5, it is clear that the DIC input to the lake originates from soil $\mathrm{CO}_{2}$ (excluding carbon from carbonate). Therefore, it could be concluded that $\mathrm{CO}_{2}$ in some lakes does not originate primarily from the input of soil organic matter from catchments, but from soil $\mathrm{CO}_{2}$. The $\mathrm{CO}_{2}$ emissions in this kind of lake are one way that soil $\mathrm{CO}_{2}$ returns to the atmosphere, although there are often small differences in isotopic compositions and ages of $\mathrm{CO}_{2}$ between that evaded from waters and that evaded directly from soils (Leith et al., 2014) and between that produced in surface versus deep soils (Ding et al., 2010). This view is in accord with the conventional carbon cycle that blends outgassing from aquatic systems with terrestrial respiration (see Battin et al., 2009).

\subsection{Lake $\mathrm{CO}_{2}$ Emissions Derived From Organic and Inorganic Origins Have Different Impacts on the Adjustment of Local Carbon Budget}

The lake $\mathrm{CO}_{2}$ derived from organic and inorganic origins has different sources and cycling pathways (Table 3) and thus requires different methods to integrate them into landscape carbon cycles (Figures $6 \mathrm{a}$ and $6 \mathrm{~b}$ ). If the lake $\mathrm{CO}_{2}$ is produced by in-lake mineralization of soil organic matter input from the catchment, it belongs to exported ecosystem production and thus should be included in the estimate of terrestrial NEP (Figure 6a), as done in previous studies (Bastviken et al., 2011; Cole et al., 2007; Tranvik et al., 2009). Including groundwater and stream $\mathrm{CO}_{2}$ evasion, the amounts of aquatic $\mathrm{CO}_{2}$ emitted reached $4.4 \mathrm{~g} \mathrm{C} \mathrm{m}^{-2} \mathrm{a}^{-1}$. This is equal to $55 \%$ of the catchment NEP (assuming an average NEP of $-8 \mathrm{~g} \mathrm{C} \mathrm{m}^{-2} \mathrm{a}^{-1}$, Table 1). In the lake, the sum of $\mathrm{CO}_{2}$ emission and OC burial equals $24 \%$ of the catchment NEP. These percentages indicate that aquatic $\mathrm{CO}_{2}$ emission, given an organic origin, might account for a large proportion of catchment NEP, possibly altering the estimate of carbon balance of the terrestrial ecosystem. Release to the atmosphere of amounts of carbon equaling $13 \%$ of NEP (Figure $6 \mathrm{a}$ ) is enough to exert influence on change of atmospheric $\mathrm{CO}_{2}$ concentrations, as the result is extrapolated to the entire globe.

In comparison, lake $\mathrm{CO}_{2}$ derived from inorganic origin has a completely different nature from that of organic origins (Table 3). Essentially, the $\mathrm{CO}_{2}$ derived from inorganic origins belongs to soil $\mathrm{CO}_{2}$ (as shown in Figure 5), 
Table 3

Comparisons in Nature, Contribution, and Assessment of Lake Carbon Between Organic Origins and Inorganic Origins

\begin{tabular}{|c|c|c|c|}
\hline For lake $\mathrm{CO}_{2}$ & & Organic origins & Inorganic origins \\
\hline \multirow[t]{7}{*}{$\mathrm{CO}_{2}$ emission } & Sources & Soil OC & Soil $\mathrm{CO}_{2}$ \\
\hline & Attributes & NEP & Soil $A R$ and $H R$ \\
\hline & Turnover rates in systems & Slow & Fast \\
\hline & Residence times in systems & Long & Short \\
\hline & Impact on adjusting terrestrial $\mathrm{C}$ budget & Significant impact & No significant impact \\
\hline & How to integrate in landscape carbon cycling & Included in NEP & Included into soil $\mathrm{CO}_{2}$ efflux \\
\hline & Contribution on atmospheric $\mathrm{CO}_{2}$ change & $\mathrm{CO}_{2}$ source & No significant effect \\
\hline For lake OC & & Allochthonous OC & Autochthonous OC \\
\hline \multirow[t]{2}{*}{ OC b burial } & OC mineralization & Carbon source & No significant effect \\
\hline & $\begin{array}{l}\text { OC escape mineralization } \\
\text { ( } C \text { sequestration) }\end{array}$ & Carbon sink & Net carbon sink \\
\hline Net effect of lakes/reservoirs & & $\begin{array}{l}\text { Depending on the ratio of } \\
\mathrm{CO}_{2} \text { efflux to } \mathrm{OC} \text { burial }\end{array}$ & $\begin{array}{l}\text { Depending on the difference between } \\
\text { catchment NEP and OC burial }\end{array}$ \\
\hline
\end{tabular}

which is produced by autotrophic and HR in soils. NEP is restricted to OC balance and excludes IC (Chapin et al., 2006; Lovett et al., 2006). Therefore, lake $\mathrm{CO}_{2}$ emissions derived from inorganic origin have no effect on the terrestrial NEP. Aquatic $\mathrm{CO}_{2}$ evasion accounts for a very small percentage $(<0.1 \%)$ of soil $\mathrm{CO}_{2}$ efflux (Figure $6 \mathrm{~b}$ ). With so small a proportion, lake $\mathrm{CO}_{2}$ evasion has little potential to significantly alter the concentration of atmospheric $\mathrm{CO}_{2}$. The comparison (Figures $6 \mathrm{a}$ and $6 \mathrm{~b}$ ) indicates that whether lake $\mathrm{CO}_{2}$ evasion requires an adjustment of the terrestrial carbon budget, and alters atmospheric $\mathrm{CO}_{2}$ concentrations, depends on carbon origins, even though the amounts of $\mathrm{CO}_{2}$ emission are equal. The difference is caused by cycling rates of IC and OC in the catchment-lake system (Table 3). IC has a much faster turnover rate and far shorter residence times, relative to OC (Raich \& Schlesinger, 1992). Especially, the carbon from root respiration has the fastest turnover rate and shortest residence time, lasting a few minutes to a few hours in the plant-soil system (see Hanson et al., 2000; Kuzyakov, 2006). Because of this, carbon used for root and rhizo-microbial respiration has no effect on long-term carbon balances (Kuzyakov, 2006). The significance of lake $\mathrm{CO}_{2}$ evasion to local and global carbon budgets might be overstated if the $\mathrm{CO}_{2}$ that has short residence time and little influence is regarded as the one that has long residence time and large potential to alter landscape carbon budgets (Table 3 ). Therefore, partitioning the
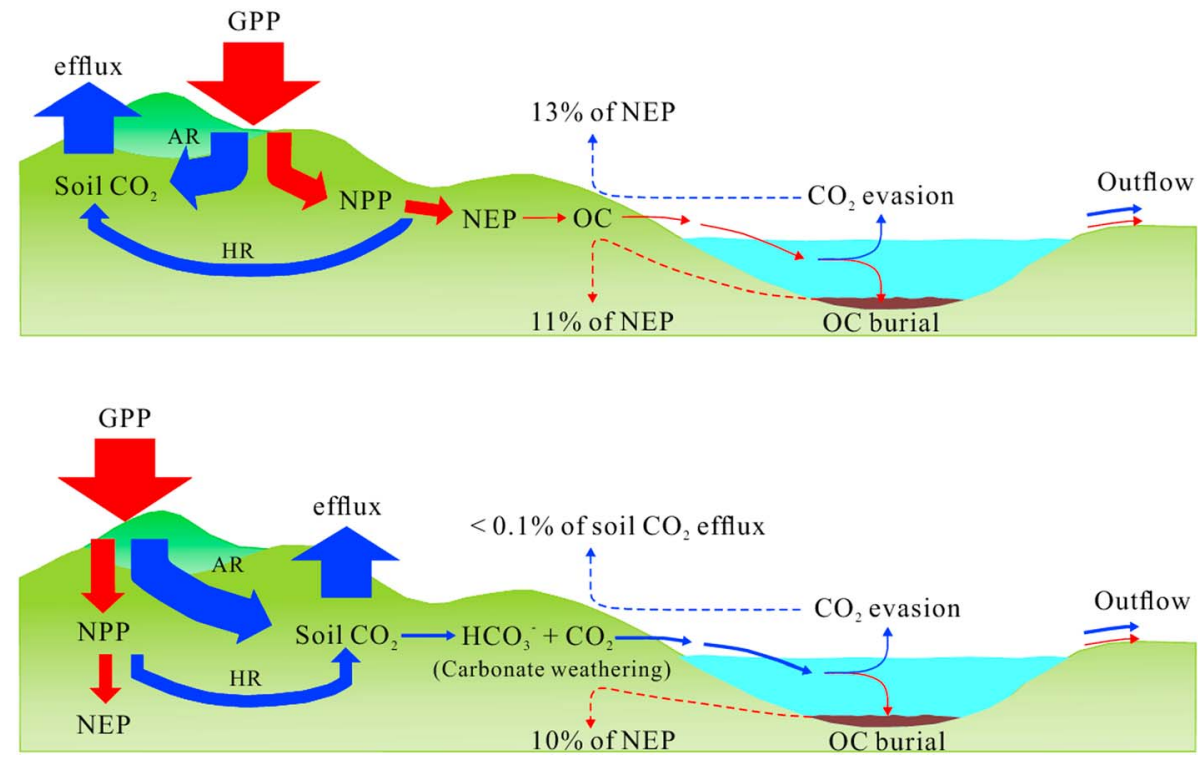

Figure 6. Comparisons of transfers and effluxes of organic (red arrows) and inorganic carbon (blue arrows) between the soil-air interface and the lake water-air interface, on the basis of (a) organic and (b) inorganic origins of lake carbon. The size of the arrows reflects relative magnitudes. The broken lines exhibit the carbon source/sink strength of the reservoir. 
contribution of autotrophic and HR in soils and in-lake mineralization of soil OC is a crucial step to assess the effect of $\mathrm{CO}_{2}$ emission on local carbon cycling.

\subsection{OC Burial in the Lake Sediment Is a Net Sink}

Allochthonous $\mathrm{OC}$ is a part of terrestrial primary production, while autochthonous $\mathrm{OC}$ stored in lake sediments might comprise a net carbon sink if atmospheric $\mathrm{CO}_{2}$ is utilized in $\mathrm{OC}$ production by photosynthesis (Figure 6b). According to results from the nearby Puding reservoir, $\mathrm{C} / \mathrm{N}$ ratios of allochthonous organic matter are approximately 45.0 , and $\mathrm{C} / \mathrm{N}$ ratios of autochthonous organic matter are about 5.0. If these ratios are regarded as end-members, it could be estimated using simple mixing models that $\sim 85 \%$ of OC stored in the lake sediment was produced by photosynthesis within the lake, and just $15 \%$ was supplied from input of terrestrially derived OM (Figure 4). It is the $\mathrm{HCO}_{3}{ }^{-}$supplied from the catchment that was utilized during photosynthesis as a carbon source to form the autochthonous organic matter (Wang et al., 2015). This $\mathrm{HCO}_{3}{ }^{-}$originated from input of soil $\mathrm{CO}_{2}$ dissolving carbonate, most of which was from root respiration with a very short residence times (Figure $6 \mathrm{~b}$ ). Burial of autochthonous $\mathrm{OC}$ in the lake sediment greatly extends the residence time of carbon, from hours to decades to thousands of years. Therefore, $\mathrm{OC}$ sequestration in the lake sediment could be a net sink of carbon. Expressed per catchment area, $\sim 0.77 \mathrm{~g} \mathrm{~m}^{-2} \mathrm{a}^{-1}$ of autochthonous OC was finally stored in the sediment as a net sink (Figure $6 \mathrm{~b}$ ), which is slightly lower than the lower range of values (1-4 $\mathrm{g} \mathrm{C} \mathrm{m}^{-2} \mathrm{a}^{-1}$ ) of atmospheric carbon withdrawal rates in lakes reported by Einsele et al. (2001).

\subsection{Accurately Assessing the Roles of Lakes and Reservoirs in the Context of Organic and Inorganic Carbon Cycling}

The methods of assessing the net environmental effect of lakes in terms of carbon source/sink strength differ depending on the origins of lake carbon. In previous studies, the ratio of gaseous carbon evasion to the atmosphere to OC burial in sediments was generally viewed as a value that characterizes the effect to be negative $(>1)$, positive $(<1)$, or neutral ( 1) (Hanson et al., 2004; Mendonça et al., 2012). However, it should be noted that sources of aquatic carbon were not taken into consideration in estimating the ratio values.

In the scenario of a primarily $\mathrm{OC}$ origin (Figure $6 \mathrm{a}$ ), $\mathrm{CO}_{2}$ evasion in the lake would function as a source of atmospheric carbon, if stable $\mathrm{OC}$ in soils is decomposed at a faster rate. OC burial is not a sink of atmospheric $\mathrm{CO}_{2}$ unless the decomposable $\mathrm{OC}$ in soils escape mineralization and is stored in the sediments for a long time. Simply, the ratio of $\mathrm{CO}_{2}$ evasion to $\mathrm{OC}$ burial represents the vertical allocation of exported oC between decomposition and deposition and thus is able to reflect the role of lakes in deciding the fate of OC from the catchment (Hanson et al., 2004). The comparison between catchment NEP and aquatic $\mathrm{CO}_{2}$ emission that has often been done in previous studies could reflect the ability of lakes to convert exported OC into gaseous carbon; therefore, these parameters could approximately reflect the source/sink strength of lakes, given the lake $\mathrm{CO}_{2}$ is of organic origin.

In contrast, in the scenario of a primarily IC origin, aquatic $\mathrm{CO}_{2}$ is produced by processes other than $\mathrm{OC}$ decomposition (equations (1)-(3) in Figure 5). $\mathrm{CO}_{2}$ evasion could not be regarded as an effective source of atmospheric carbon, but $\mathrm{OC}$ burial is a net sink for atmospheric carbon. The ratio of gaseous carbon evasion and OC burial may not be an appropriate parameter for assessing the source/sink strength of the lake. We argue that the differences between NEP and OC burial might be a more reasonable proxy to denote the net environmental effect of the lake on a catchment scale (Figure $6 \mathrm{~b}$ ), given that lake $\mathrm{CO}_{2}$ is primarily of inorganic origin. At Lake Hongfeng, the ratio of $\mathrm{CO}_{2}$ evasion to $\mathrm{OC}$ burial is $\sim 1.11(1.1 / 0.9)$, suggesting that the lake acts as a weak net source of atmospheric carbon on the basis of prior standard (Hanson et al., 2004; Mendonça et al., 2012). However, the autochthonous OC burial rate of $43.4 \mathrm{~g} \mathrm{C} \mathrm{m}^{-2} \mathrm{a}^{-1}\left(9.9 \mathrm{mmol} \mathrm{m}^{-2} \mathrm{~d}^{-1}\right.$, Table 1) in the lake sediment is larger than NEP $\left(-20.0\right.$ to $\left.0 \mathrm{~g} \mathrm{C} \mathrm{m}^{-2} \mathrm{a}^{-1}\right)$ in the catchment, meaning that the reservoir has much greater carbon sequestration than the catchment (as long as the calculation is done on a per area basis). The rate of lake $\mathrm{CO}_{2}$ emission sharply decreases relative to soil $\mathrm{CO}_{2}$ efflux, and carbon sequestration markedly increases relative to NEP after impoundment (Figure 6b). Therefore, the reservoir plays an important role as a net sink of atmospheric carbon, if little or none of the emitted $\mathrm{CO}_{2}$ came from mineralization of soil-derived $\mathrm{OC}$ in situ. This comparison demonstrates that different methods are needed to assess the source/sink strength of lake emissions and OC burial depending on carbon origins. 


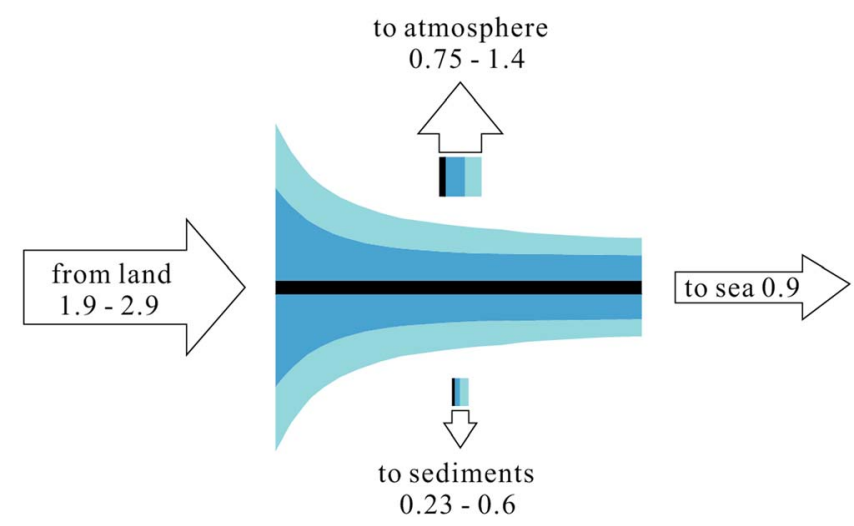

Figure 7. Partitioning aquatic carbon fluxes between organic and inorganic origins. The "active pipe" hypothesis was advanced by Cole et al. (2007) and revised by Aufdenkampe et al. (2011), Tranvik et al. (2009), and others (units: $\mathrm{Pg} \mathrm{Ca}{ }^{-1}$. The black color denotes carbon from carbonate, the dark gray color denotes carbon from inorganic origin, and the light gray color denotes carbon from organic origin. For data see Aufdenkampe et al. (2011), Cole et al. (2007), Nakayama (2017), Regnier et al. (2013), and Tranvik et al. (2009).
The conclusion drawn here has important implications concerning the significance of inland waters fluxes to the global carbon budget. While this research is based on study of only a single lake, the reality that lake carbon is, or can be, of predominantly inorganic origin is a likely condition in many catchments and lakes around the world. In carbonate areas, carbonate weathering drives soil $\mathrm{CO}_{2}$ to transform into $\mathrm{HCO}_{3}{ }^{-}$, and that $\mathrm{IC}$ makes up a larger percentage of catchment carbon export. In fact, even where carbonates comprise as little as $5 \%$ of exposed bedrock, carbonate weathering still has an important influence on water chemistry (Barth et al., 2003). Tian et al.'s (2015) modeling shows that DIC flux exceeds the sum of DOC and POC fluxes in eastern North America. In many lakes around the world, input loading of DIC exceeds that of OC (Hanson et al., 2004; Tranvik et al., 2009), indicating that the influence of DIC on aquatic carbon balances cannot be neglected. NEP is restricted to the imbalance between GPP and ecosystem respiration; represents the total amount of OC in an ecosystem available for storage, export, and consumption by nonbiological oxidation; and explicitly excludes IC (Chapin et al., 2006; Lovett et al., 2006). The widely accepted "active pipe" hypothesis concerning inland waters advanced by Cole et al. (2007) and revised by Aufdenkampe et al. (2011) and Tranvik et al. (2009) does not include $\mathrm{CO}_{2}$ derived from inorganic sources. But, in actual observations, the contribution of $\mathrm{CO}_{2}$ from inorganic sources to aquatic $\mathrm{CO}_{2}$ efflux must exist. Therefore, there must be a discrepancy between theoretical models and observational data.

One method of improving the conceptual model is to partition the aquatic carbon fluxes between organic and inorganic origins (Figure 7). The flux of carbon transferred from terrestrial ecosystems to sea, efflux of aquatic $\mathrm{CO}_{2}$, and the flux of $\mathrm{OC}$ burial could be divided into three types: the carbon from carbonate (due to erosion), from inorganic origin, and from organic origin (Figure 7). Many studies have given the terrestrial export fluxes of these three kinds of carbon (e.g., Ludwig et al., 2011; Nakayama, 2017; Tian et al., 2015). However, their contribution to $\mathrm{CO}_{2}$ efflux and $\mathrm{OC}$ burial is not well constrained.

The mechanisms controlling aquatic $\mathrm{CO}_{2}$ emissions and $\mathrm{OC}$ burial remain poorly constrained (e.g., Barros et al., 2011; Cole, 2013; Marx et al., 2017; Nakayama, 2017; Raymond et al., 2013; Regnier et al., 2013; Tian et al., 2015). On average, just $28 \%$ of river $\mathrm{CO}_{2}$ is from the mineralization of terrestrial OC input (Hotchkiss et al., 2015). In lakes, this proportion is likely to change over a large range. In subtropical areas where carbonates are widely distributed (Ludwig et al., 2011), like at Lake Hongfeng, the $\mathrm{CO}_{2}$ sourced from inorganic origin is dominant. In boreal and Arctic/subarctic areas which have high DOC loads, the contribution of allochthonous OC may be as high as $85 \%$ (Hanson et al., 2004). Cole et al. (2002) and Hanson et al. (2004) found that $40-52 \%$ of inlake respiration is supported by allochthonous OC. Combining the results from groundwater, stream water, and lake water, it is likely that $<50 \%$ of the aquatic $\mathrm{CO}_{2}$ evasion flux belongs to catchment NEP. Only this fraction of the flux should be considered in the estimate of catchment NEP. The carbon sourced from inorganic origin could be further divided into heterotrophic and autotrophic fractions. The heterotrophic fraction is derived from decomposition of soil OC; thus, this part of the flux could be considered in the estimate of terrestrial NPP, while the autotrophic fraction is derived from root-related respiration in soil and has no effect on long-term carbon cycling. A conservative estimate would be that $\sim 50 \%$ of soil $\mathrm{CO}_{2}$ is derived from root respiration (Hanson et al., 2000). This means that just a small fraction of the fluxes of aquatic $\mathrm{CO}_{2}$ evasion could have a large influence on medium- and long-term changes of atmospheric $\mathrm{CO}_{2}$ concentrations and on terrestrial carbon balances. A careful reassessment of the significances of $\mathrm{CO}_{2}$ evasion and OC burial in freshwater ecosystems to local and global carbon budget, with full consideration of their sources, is necessary and pressing.

\section{Conclusions}

Lake Hongfeng emitted $\mathrm{CO}_{2}$ and simultaneously sequestrated $\mathrm{OC}$ into the sediments at nearly the same rate. Overall, the rate of $\mathrm{CO}_{2}$ emission across the lake water-air interface ranged from 7.0 to $19.0 \mathrm{mmol} \mathrm{m}^{-2} \mathrm{~d}^{-1}$, 
with an average of $11.5 \pm 2.6 \mathrm{mmol} \mathrm{m} \mathrm{m}^{-2} \mathrm{~d}^{-1}\left(1.0 \pm 0.2 \mathrm{~g} \mathrm{C} \mathrm{m}^{-2} \mathrm{a}^{-1}\right.$, per unit catchment area). Including groundwater and stream water $\mathrm{CO}_{2}$ degassing, total aquatic $\mathrm{CO}_{2}$ evasion in this catchment was as high as $4.4 \mathrm{~g} \mathrm{C} \mathrm{m}^{-2} \mathrm{a}^{-1}$. At the sediment-water interface, $69 \%$ of the OC delivered to the interface was remineralized during burial, and the remainder was stored in the sediment at a rate of $0.9 \pm 0.2 \mathrm{~g} \mathrm{C} \mathrm{m}^{-2} \mathrm{a}^{-1}$ (per unit catchment area).

Integrating the $\mathrm{CO}_{2}$ evasion and $\mathrm{OC}$ burial in the lake in the context of inorganic and $\mathrm{OC}$ cycling in the catchment, we constructed a complete carbon budget in the catchment-lake system including all vertical and horizontal fluxes of IC and OC. Results show that carbon export from the catchment in the form of DIC species $\left(8.3 \mathrm{~g} \mathrm{C} \mathrm{m}^{-2} \mathrm{a}^{-1}\right)$ is about 8 times that in the form of OC species $\left(1.1 \mathrm{~g} \mathrm{C} \mathrm{m}^{-2} \mathrm{a}^{-1}\right)$. Carbonate dissolution rapidly and constantly consumed soil $\mathrm{CO}_{2}$ to form $\mathrm{HCO}_{3}{ }^{-}$, which was subsequently delivered to waters, and accelerated the processes of catchment carbon transfer. Comparisons of carbon fluxes in the catchment suggest that the lake carbon primarily originated from soil $\mathrm{CO}_{2}$ dissolving carbonate, rather than from $\mathrm{OC}$ from the catchment.

Carbon pathway-based analysis shows that aquatic $\mathrm{CO}_{2}$ derived from organic and inorganic origins have different significance in terms of the terrestrial carbon budget. The sum of $\mathrm{CO}_{2}$ emissions and $\mathrm{OC}$ burial in the lake equaled $24 \%$ of catchment NEP, meaning that lake carbon fluxes could alter the estimate of carbon balance of the terrestrial ecosystem if the carbon was derived from organic origin. However, lake $\mathrm{CO}_{2}$ originated from soil $\mathrm{CO}_{2}$ (and $\mathrm{HCO}_{3}{ }^{-}$), which accounts for a small percentage $(<0.1 \%)$ of the total soil $\mathrm{CO}_{2}$ efflux. Therefore, it has little potential to significantly alter the terrestrial carbon budget and atmospheric $\mathrm{CO}_{2}$ concentration in medium and long term. This comparison indicates the importance of aquatic $\mathrm{CO}_{2}$ evasion and the need to adjust the catchment carbon budget considering explicitly the origins of carbon.

Based on the ratio of gaseous carbon evasion to OC burial, Lake Hongfeng is a weak carbon source. In the scenario of a primarily IC origin, $\mathrm{CO}_{2}$ evasion from the lake is not a significant source of atmospheric carbon, but OC burial is a net sink for atmospheric carbon. The differences between NEP and OC burial, instead of the above ratio, may be a more reasonable proxy to denote the source/sink strength of lakes. The autochthonous OC burial rate of $43.4 \mathrm{~g} \mathrm{C} \mathrm{m}^{-2} \mathrm{a}^{-1}$ in the sediment is far larger than NEP $\left(-20.0\right.$ to $\left.0 \mathrm{~g} \mathrm{C} \mathrm{m}^{-2} \mathrm{a}^{-1}\right)$ in the catchment, meaning that the reservoir actually plays an important role in serving as a net sink of atmospheric carbon. The conclusion suggests that aquatic carbon derived from different origins must be considered independently in understanding the role of lakes and reservoirs to local and global carbon budget.

\section{Acknowledgments}

This research was supported by the National Key Research and Development Program of China (2016YFA0601003) and the National Natural Science Foundation of China (91547117, 41373137, and U1612442). All the data obtained in 2013 and 2015 are listed in Appendix as supporting information, and the data for 2001 to 2004 are available in Wang et al. (2015) We thank the editor and two anonymous reviewers for their constructive remarks that improved this work greatly.

\section{References}

Abril, G., Martinez, J. M., Artigas, L. F., Moreira-Turcq, P., Benedetti, M. F., Vidal, L., et al. (2014). Amazon River carbon dioxide outgassing fueled by wetlands. Nature, 505(7483), 395-398. https://doi.org/10.1038/nature12797

Ask, J., Karlsson, J., \& Jansson, M. (2012). Net ecosystem production in clear-water and brown-water lakes. Global Biogeochemical Cycles, 26, GB1017. https://doi.org/10.1029/2010GB003951

Aufdenkampe, A. K., Mayorga, E., Raymond, P. A., Melack, J. M., Doney, S. C., Alin, S. R., et al. (2011). Riverine coupling of biogeochemical cycles between land, oceans, and atmosphere. Frontiers in Ecology and the Environment, 9(1), 53-60. https://doi.org/10.1890/100014

Barros, N., Cole, J. J., Tranvik, L. J., Prairie, Y. T., Bastviken, D., Huszar, V. L. M., et al. (2011). Carbon emission from hydroelectric reservoirs linked to reservoir age and latitude. Nature Geoscience, 4(9), 593-596. https://doi.org/10.1038/ngeo1211

Barth, J. A. C., Cronin, A. A., Dunlop, J., \& Kalin, R. M. (2003). Influence of carbonates on the riverine carbon cycle in an anthropogenically dominated catchment basin: Evidence from major elements and stable carbon isotopes in the Lagan River (N. Ireland). Chemical Geology, 200(3-4), 203-216. https://doi.org/10.1016/s0009-2541(03)00193-1

Bastviken, D., Tranvik, L. J., Downing, J. A., Crill, P. M., \& Enrich-Prast, A. (2011). Freshwater methane emissions offset the continental carbon sink. Science, 331(6013), 50. https://doi.org/10.1126/science.1196808

Battin, T. J., Luyssaert, S., Kaplan, L. A., Aufdenkampe, A. K., Richter, A., \& Tranvik, L. J. (2009). The boundless carbon cycle. Nature Geoscience, 2(9), 598-600. https://doi.org/10.1038/ngeo618

Buffam, I., Turner, M. G., Desai, A. R., Hanson, P. C., Rusak, J. A., Lottig, N. R., et al. (2011). Integrating aquatic and terrestrial components to construct a complete carbon budget for a north temperate lake district. Global Change Biology, 17(2), 1193-1211. https://doi.org/10.1111/ j.1365-2486.2010.02313.x

Butman, D., \& Raymond, P. A. (2011). Significant efflux of carbon dioxide from streams and rivers in the United States. Nature Geoscience, 4(12), 839-842. https://doi.org/10.1038/ngeo1294

Butman, D., Stackpoole, S., Stets, E., McDonald, C. P., Clow, D. W., \& Striegl, R. G. (2016). Aquatic carbon cycling in the conterminous United States and implications for terrestrial carbon accounting. Proceedings of the National Academy of Sciences of the United States of America, 113, 58-63. https://doi.org/10.1073/pnas.1512651112

Cao, J. H., Yang, H., \& Kang, Z. Q. (2011). Preliminary regional estimation of carbon sink flux by carbonate rock corrosion: A case study of the Pearl River basin. Chinese Science Bulletin, 56(35), 3766-3773. https://doi.org/10.1007/s11434-011-4377-3

Cao, M., Prince, S. D., Li, K., Tao, B., Small, J., \& Shao, X. (2003). Response of terrestrial carbon uptake to climate interannual variability in China. Global Change Biology, 9(4), 536-546. https://doi.org/10.1046/j.1365-2486.2003.00617.x 
Chapin, F. S., Woodwell, G. M., Randerson, J. T., Rastettere, E. B., Lovett, G. M., Baldocchi, D. D., et al. (2006). Reconciling carbon-cycle concepts, terminology, and methods. Ecosystems, 9(7), 1041-1050. https://doi.org/10.1007/s10021-005-0105-7

Christensen, T. R., Johansson, T., Olsrud, M., Strǒm, L., Lindroth, A., Mastepanov, M., et al. (2007). A catchment-scale carbon and greenhouse gas budget of a subarctic landscape. Philosophical Tansactions of the Royal Society A, 365(1856), 1643-1656. https://doi.org/10.1098/ rsta.2007.2035

Cole, J. (2013). Freshwater in flux. Nature Geoscience, 6(1), 13-14. https://doi.org/10.1038/ngeo1696

Cole, J. J., \& Caraco, N. F. (2001). Carbon in catchments: Connecting terrestrial carbon losses with aquatic metabolism. Marine and Freshwater Research, 52(1), 101-110. https://doi.org/10.1071/MF00084\%201323-1650/01/010101

Cole, J. J., Caraco, N. F., Kling, G. W., \& Kratz, T. K. (1994). Carbon dioxide supersaturation in the surface waters of lakes. Science, 265(5178), 1568-1570. https://doi.org/10.1126/science.265.5178.1568

Cole, J. J., Carpenter, S. R., Kitchell, J. F., \& Pace, M. L. (2002). Pathways of organic carbon utilization in small lakes: Results from a whole-lake ${ }^{13} \mathrm{C}$ addition and coupled model. Limnology and Oceanography, 47(6), 1664-1675. https://doi.org/10.4319/lo.2002.47.6.1664

Cole, J. J., Prairie, Y. T., Caraco, N. F., McDowell, W. H., Tranvik, L. J., Striegl, R. G., et al. (2007). Plumbing the global carbon cycle: Integrating inland waters into the terrestrial carbon budget. Ecosystems, 10(1), 172-185. https://doi.org/10.1007/s10021-006-9013-8

Dean, W. E., \& Gorham, E. (1998). Magnitude and significance of carbon burial in lakes, reservoirs, and peatlands. Geology, 26(6), 535-538. https://doi.org/10.1130/0091-7613

Ding, P., Shen, C. D., Wang, N., Yi, W. X., Ding, X. F., Fu, D. P., et al. (2010). Carbon isotopic composition, turnover and origins of soil $\mathrm{CO}_{2}$ in a monsoon evergreen broad leaf forest in Dinghushan Biosphere Reservoir, South China. Chinese Science Bulletin, 55, 2548-2556. https://doi. org/10.1007/s11434-010-0072-z

Dong, D., \& Ni, J. (2011). Modeling changes of net primary productivity of karst vegetation in southwestern China using the CASA model. Acto Ecologica Sinica, 31, 1855-1866.

Downing, J. A., Cole, J. J., Middelburg, J. J., Striegl, R. G., Duarte, C. M., Kortelainen, P., et al. (2008). Sediment organic carbon burial in agriculturally eutrophic impoundments over the last century. Global Biogeochemical Cycles, 22, GB1018. https://doi.org/10.1029/ 2006GB002854

Duarte, C. M., \& Agusti, S. (1998). The $\mathrm{CO}_{2}$ balance of unproductive aquatic ecosystems. Science, 281(5374), 234-236. https://doi.org/10.1126/ science.281.5374.234

Einarsdottir, K., Wallin, M. B., \& Sobek, S. (2017). High terrestrial carbon load via groundwater to a boreal lake dominated by surface water inflow. Journal of Geophysical Research: Biogeosciences, 122, 15-29. https://doi.org/10.1002/2016JG003495

Einsele, G., Yan, J., \& Hinderer, M. (2001). Atmospheric carbon burial in modern lake basins and its significance for the global carbon budget. Global and Planetary Change, 30(3-4), 167-195. https://doi.org/10.1016/S0921-8181\%20(01)00105-9

Finlay, K., Leavitt, P. R., Wissel, B., \& Prairie, Y. T. (2009). Regulation of spatial and temporal variability of carbon flux in six hard-water lakes of the northern Great Plains. Limnology and Oceanography, 54(6part2), 2553-2564. https://doi.org/10.4319/lo.2009.54.6\%20part\%202.2553

Gombert, P. (2002). Role of karstic dissolution in global carbon cycle. Global and Planetary Change, 33(1-2), 177-184. https://doi.org/10.1016/ S0921-8181(02)00069-3

Gu, X. P., Huang, M., Ji, J. J., \& Wu, Z. P. (2007). The influence of climate change on vegetation net primary productivity in southwestern China during recent 20 years period. Journal of Natural Resources, 22, 251-259. https://doi.org/10.11849/zrzyxb.2007.02.012

Han, G., \& Liu, C. (2004). Water geochemistry controlled by carbonate dissolution: A study of the river waters draining karst-dominated terrain, Guizhou Province, China. Chemical Geology, 204, 1-21. https://doi.org/10.1016/j.chemgeo.2003.09.009

Hanson, P. C., Pace, M. L., Carpenter, S. R., Cole, J. J., \& Stanley, E. H. (2015). Integrating landscape carbon cycling: Research needs for resolving organic carbon budgets of lakes. Ecosystems, 18(3), 363-375. https://doi.org/10.1007/s10021-014-9826-9

Hanson, P. C., Pollard, A. I., Bade, D. L., Predick, K., Carptenter, S. R., \& Foley, J. A. (2004). A model of carbon evasion and sedimentation in temperate lakes. Global Change Biology, 10(8), 1285-1298. https://doi.org/10.1111/j.1365-2486.2004.00805.x

Hanson, P. J., Edwards, N. T., Garten, C. T., \& Andrews, J. A. (2000). Separating root and soil microbial contributions to soil respiration: A review of methods and observations. Biogeochemistry, 48(1), 115-146. https://doi.org/10.1023/A:1006244819642

Hotchkiss, E. R., Hall Jr, R. O., Sponseller, R. A., Butman, D., Klaminder, J., Laudon, H., et al. (2015). Sources of and processes controlling CO emissions change with the size of streams and rivers. Nature Geoscience, 8(9), 696-699. https://doi.org/10.1038/ngeo2507

Jones, R. I., Grey, J., Quarmby, C., \& Sleep, D. (2001). Sources and flues of inorganic carbon in a deep, oligotrophic lake (Loch Ness, Scotland). Global Biogeochemical Cycles, 15(4), 863-870. https://doi.org/10.1029/2001GB001423

Jonsson, A., Algesten, G., Bergström, A.-K., Bishop, K., Sobek, S., Tranvik, L. J., \& Jansson, M. (2007). Integrating aquatic carbon fluxes in a boreal catchment carbon budget. Journal of Hydrology, 334(1-2), 141-150. https://doi.org/10.1016/j.jhydrol.2006.10.003

Kayranli, B., Scholz, M., Mustafa, A., \& Hedmark, Å. (2010). Carbon storage and fluxes within freshwater wetlands: A critical review. Wetlands, 30(1), 111-124. https://doi.org/10.1007/s13157-009-0003-4

Ke, J. H., Piao, S. L., \& Fang, J. Y. (2003). NPP and its spatial-temporal patterns in the Yangtze River watershed. Acta Phytoecologica Sinica, 27(6), 764-771. https://doi.org/10.17521/cjpe.2003.0109

Kling, G. W., Kipphut, G. W., \& Miller, M. C. (1991). Arctic lakes and streams as gas conduits to the atmosphere-Implications for tundra carbon budgets. Science, 251(4991), 298-301. https://doi.org/10.1126/science.251.4991.298

Kuzyakov, Y. (2006). Sources of $\mathrm{CO}_{2}$ efflux from soil and review of partitioning methods. Soil Biology and Biochemistry, 38(3), 425-448. https:// doi.org/10.1016/j.soilbio.2005.08.020

Leith, F. I., Dinsmore, K. J., Wallin, M. B., Billett, M. F., Heal, K. V., Laudon, H., et al. (2015). Carbon dioxide transport across the hillslope-riparianstream continuum in a boreal headwater catchment. Biogeosciences, 12, 1881-1892. https://doi.org/10.5194/bg-12-1881-2015

Leith, F. I., Garnett, M. H., Dinsmore, K. J., Billett, M. F., \& Heal, K. V. (2014). Source and age of dissolved and gaseous carbon in a peatland-riparianstream continuum: A dual isotope $\left({ }^{14} \mathrm{C}\right.$ and $\left.\delta^{13} \mathrm{C}\right)$ analysis. Biogeochemistry, 119(1-3), 415-433. https://doi.org/10.1007/s10533-014-9977-y

Liu, F., Liu, C.-Q., Wang, S. L., \& Zhu, Z. J. (2012). Soil temperature and moisture controls on surface fluxes and profile concentrations of greenhouse gases in karst area in central part of Guizhou Province, southwest China. Environmental Earth Sciences, 67(5), 1431-1439. https://doi.org/10.1007/s12665-012-1588-0

Liu, L. (2017). Vegetation biomass and net primary productivity and their model parameterization in the karst region of southwestern China: From plot investigation to regional synthesis and simulation, (PhD dissertation). Institute of Geochemistry, Chinese Academy of Sciences.

Lovett, G. M., Cole, J. J., \& Pace, M. L. (2006). Is net ecosystem production equal to ecosystem carbon accumulation? Ecosystems, 9(1), 152-155. https://doi.org/10.1007/s10021-005-0036-3

Ludwig, W., Amiotte-Suchet, P., \& Probst, J.-L. (2011). ISLSCP II atmospheric carbon dioxide consumption by continental erosion. In G. Forrest, et al. (Eds.), ISLSCP initiative I/ collection. Data set. Hall. Oak Ridge Natl. Lab. Distributed Active Archive Center, Oak Ridge, TN. Retrieved from http://daac.ornl.gov/ISLSP_II/guides/atmos_ $\mathrm{CO}_{2}$ by-erosion_xdeg.html 
Lundin, E. J., Klaminder, J., Bastviken, D., Olid, C., Hansson, S. V., \& Karlsson, J. (2015). Large difference in carbon emission-burial balances between boreal and arctic lakes. Scientific Reports, 5(1), 14248. https://doi.org/10.1038/srep14248

Maberly, S. C., Barker, P. A., Stott, A. W., \& de Ville, M. M. (2013). Catchment productivity controls $\mathrm{CO}_{2}$ emissions from lakes. Nature Climate Change, 3(4), 391-394. https://doi.org/10.1038/NCLIMATE1748

Marcé, R., Obrador, B., Morguí, J.-A., Riera, J. L., López, P., \& Armengol, J. (2015). Carbonate weathering as a driver of $\mathrm{CO}_{2}$ supersaturation in lakes. Nature Geoscience, 8(2), 107-111. https://doi.org/10.1038/ngeo2341

Marx, A., Dusek, J., Jankovec, J., Sanda, M., Vogel, T., van Geldern, R., et al. (2017). A review of $\mathrm{CO}_{2}$ and associated carbon dynamics in headwater streams: A global perspective. Reviews of Geophysics, 55, 560-585. https://doi.org/10.1002/2016RG000547

McDonald, C. P., Stets, E. G., Striegl, R. G., \& Butman, D. (2013). Inorganic carbon loading as a primary driver of dissolved carbon dioxide concentrations in the lakes and reservoirs of the contiguous Unites States. Global Biogeochemical Cycles, 27, 285-295. https://doi.org/ 10.1002/gbc.20032

Mendonça, R., Kosten, S., Sobek, S., Barros, N., Cole, J. J., Tranvik, L., \& Roland, F. (2012). Hydroelectric carbon sequestration. Nature Geoscience, 5(12), 838-840. https://doi.org/10.1038/ngeo1653

Mo, J. M., Fang, Y. T., Xu, G. L., Li, D. J., \& Xue, J. H. (2005). The short-term responses of soil $\mathrm{CO}_{2}$ emission and $\mathrm{CH}_{4}$ uptake to simulated $\mathrm{N}$ deposition in nursery and forests of Dinghushan in subtropical China. Acta Ecologica Sinica, 25, 682-690.

Nakayama, T. (2017). Development of an advanced eco-hydrologic and biogeochemical coupling model aimed at clarifying the missing role of inland water in the global biogeochemical cycles. Journal of Geophysical Research: Biogeosciences, 122, 966-988. https://doi.org/ 10.1002/2016JG003743

Ni, J., Luo, D. H., Xia, J., Zhang, Z. H., \& Hu, G. (2015). Vegetation in karst terrain of southwestern China allocates more biomass to roots. Solid Earth, 6(3), 799-810. https://doi.org/10.5194/se-6-799-2015

Öquist, M. G., Wallin, M., Seibert, J., Bishop, K., \& Laudon, H. (2009). Dissolved inorganic carbon export across the soil/stream interface and its fate in a boreal headwater stream. Environmental Science \& Technology, 43, 7364-7369. https://doi.org/10.1021/es900416h

Raich, J. W., \& Schlesinger, W. H. (1992). The global carbon dioxide flux in soil respiration and its relationship to vegetation and climate. Tellus B, 44(2), 81-99. https://doi.org/10.1034/j.1600-0889.1992.t01-1-00001.x

Raymond, P. A., Hartmann, J., Lauerwald, R., Sobek, S., McDonald, C., Hoover, M., et al. (2013). Global carbon dioxide emissions from inland waters. Nature, 503(7476), 355-359. https://doi.org/10.1038/nature12760

Regnier, P., Friedlingstein, P., Ciais, P., Mackenzie, F. T., Gruber, N., Janssens, I. A., et al. (2013). Anthropogenic perturbation of the carbon fluxes from land to ocean. Nature Geoscience, 6(8), 597-607. https://doi.org/10.1038/ngeo1830

Sobek, S., Algesten, G., Bergstrom, A.-K., Jansson, M., \& Tranvik, L. J. (2003). The catchment and climate regulation of $\mathrm{pCO}_{2}$ in boreal lakes. Global Change Biology, 9(4), 630-641. https://doi.org/10.1046/j.1365-2486.2003.00619.x

Strock, K. E., Theodore, N., Gawley, W. G., Ellsworth, A. C., \& Saros, J. E. (2017). Increasing dissolved organic carbon concentrations in northern boreal lakes: Implications for lake water transparency and thermal structure. Journal of Geophysical Research: Biogeosciences, 122, 1022-1035. https://doi.org/10.1002/2017JG003767

Tian, H., Yang, Q., Najjar, R. G., Ren, W., Friedrichs, M. A. M., Hopkinson, C. S., \& Pan, S. (2015). Anthropogenic and climatic influences on carbon fluxes from eastern North America to the Atlantic Ocean: A processes-based modeling study. Journal of Geophysical Research: Biogeosciences, 120, 757-772. https://doi.org/10.1002/2014JG002760

Tranvik, L. J., Downing, J. A., Cotner, J. B., Loiselle, S. A., Striegl, R. G., Ballatore, T. J., et al. (2009). Lakes and reservoirs as regulators of carbon cycling and climate. Limnology and Oceanography, 54, 2298-2314. https://doi.org/10.4319/lo

Wallin, M., Buffam, I., Öquist, M., Laudon, H., \& Bishop, K. (2010). Temporal and spatial variability of dissolved inorganic carbon in a boreal stream network: Concentrations and downstream fluxes. Journal of Geophysical Research, 115, G02014. https://doi.org/10.1029/ 2009JG001100

Wallin, M. B., Grabs, T., Buffam, I., Laudon, H., Ågren, A., Öquist, M. G., \& Bishop, K. (2013). Evasion of $\mathrm{CO}_{2}$ from streams-The dominant component of the carbon export through the aquatic conduit in a boreal landscape. Global Change Biology, 19(3), 785-797. https://doi org/10.1111/gcb.12083

Wan, G. J., Huang, R. G., Wang, C. S., \& Rong, J. (1990). Variation of vertical profile for ${ }^{210} \mathrm{Po}_{\mathrm{ex}}$ at the top of sediment in Hongfeng Lake. Chinese Science Bulletin, 35, 1910-1914.

Wang, B., Yang, S. T., \& Wang, Y. J. (2007). Estimation on net primary productivity of vegetation in karst area of Guizhou province. Carsologica Sinica, 26, 98-104

Wang, S. L., Yeager, K. M., Wan, G. J., Liu, C.-Q., Liu, F., \& Lü, Y. C. (2015). Dynamics of $\mathrm{CO}_{2}$ in a karst catchment in the southwestern plateau, China. Environmental Earth Sciences, 73(5), 2415-2427. https://doi.org/10.1007/s12665-014-3591-0

Wang, S. L., Yeager, K. M., Wan, G. J., Liu, C.-Q., Wang, Y. C., \& Lü, Y. C. (2012). Carbon export and $\mathrm{HCO}_{3}{ }^{-}$fate in carbonate catchments: A case study in the karst plateau of southwestern China. Applied Geochemistry, 27(1), 64-72. https://doi.org/10.1016/j.apgeochem.2011.09.003

Weyhenmeyer, G. A., Kosten, S., Wallin, M. B., Tranvik, L. J., Jeppesen, E., \& Roland, F. (2015). Significant fraction of $\mathrm{CO}_{2}$ emissions from boreal lakes derived from hydrologic inorganic carbon inputs. Nature Geoscience, 8(12), 933-936. https://doi.org/10.1038/ngeo2582

Wu, F. C., Qing, H. R., Wan, G. J., Tang, D. G., Huang, R. G., \& Cai, Y. R. (1997). Geochemistry of $\mathrm{HCO}_{3}{ }^{-}$at the sediment-water interface of lakes from the southwestern Chinese plateau. Water, Air, \& Soil Pollution, 99, 381-390. https://doi.org/10.1023/A:101833120

Xu, X. G., Li, W., Fujibayashi, M., Nomura, M., Sakamaki, T., Nishimura, O., \& Li, X. N. (2014). Feedback of threshold via estimating sources and composition of sedimentary organic matter across trophic gradients in freshwater lakes. Science of the Total Environment, 500-501, 373-382. https://doi.org/10.1016/j.scitotenv.2014.08.113 